Jurnal Luxnos Vol. 4, No. 1, Edisi Januari-Juni 2018

\title{
Natur Antropologi: Memahami Keragaman Potensi Humanitas Dalam Konteks Komparatif Dengan Perspektif Kristen
}

\author{
Stenly R. Paparang \\ Sekolah Tinggi Teologi Moriah Gading Serpong \\ stanleypaparang@yahoo.com
}

\begin{abstract}
This article looks at the anthropology of how humans understand and assess the ins and outs of life, and draws conclusions to be used as a guide for life in shaping moral, spiritual, comfort, peace, relationships, credibility, and legacy. Anthropology talks about a series of events in human (social) groups and the changes that occur which can be inherited or substantially revised, reinterpreted, and taken as an "academic sample" as a legacy for generations in which anthropology is re-studied. With its various types, observing anthropology requires using various methodologies and approaches. At the end of this article, I discuss biblical anthropology that looks at the totality of humanity in the light of the Scriptures.
\end{abstract}

Keywords: Anthropology, Humanity, Comparative Context

Abstrak: Artikel ini memandang antropologi tentang bagaimana manusia memahami dan menilai seluk-beluk kehidupan, dan mengambil kesimpulan untuk dijadikan pegangan hidup dalam membentuk moral, spiritual, kenyamanan, kedamaian, relasi, kredibilitas, dan legasi. Antropologi berbicara tentang rentetan peristiwa dalam kelompok manusia (sosial) dan perubahan-perubahan yang terjadi yang dapat dijadikan warisan atau revisi secara substansial, reinterpretasi, dan pengambilan "sampel akademis" sebagai warisan bagi generasi di mana antropologi itu dipelajari kembali. Dengan beragam jenisnya, mengamati antropologi perlu menggunakan berbagai metodologi dan pendekatan. Di akhir artikel ini, saya membahas antropologi biblika yang melihat totalitas manusia dalam terang Kitab Suci.

Kata Kunci: Antropologi, Humanitas, Konteks Komparatif

\section{Pendahuluan}

Humanitas perlu dituangkan dalam konteks dan proses hidup yang kompleks serta plural. Dalam ruang kemanusiaan (sifat-sifat) itu sendiri, ada banyak ragam yang muncul, baik ragam relasi, ragam konflik, ragam politik, ragam pergaulan, ragam kekeluargaan, ragam berkomunikasi, ragam kerja sama, ragam kejahatan, ragam kebaikan, ragam problematika kehidupan, dan lain sebagainya. Antropologi memberikan arah dan pemahaman bahwa kehidupan yang dijalani saat ini, adalah sebuah rentetan peristiwa yang saling terkait. Terkait karena kita berada dalam ruang "waktu" yang seyogianya masih menikmati proses waktu itu. Di samping itu, pemahaman akan nilai-nilai kemanusiaan secara umum, membawa kita pada kesimpulan bahwa "manusia adalah makhluk sosial".

Banyak tokoh antropologi yang telah membahas, mengkaji, dan menemukan berbagai fakta dan rumusan tentang manusia dan kehidupannya. Suku yang satu 
berbeda dengan suku yang lainnya. Tradisi suku yang satu, berbeda dengan suku lainnya. Meski demikian, masih ada ruang kesamaan dari suku-suku atau budayabudaya di dunia. Para tokoh antropologi telah menghasilkan sumbangsi yang berharga bagi rumpun ilmu ini dan memberikan pemahaman yang baik tentang teori-teori kemanusiaan berdasarkan pengamatan empiris mereka. Tokoh-tokoh seperti Clifford Geertz (yang membahas paradigma struktural fungsionalisme, simbolisme, dan interpretivisme simbolik), Emile Durkheim, Bronislaw Malinowski, Edward Burnett Tylor, W. Lloyd Warner, dan lainnya, telah turut menyumbangkan pengamatan dan pemikiran mereka tentang antropologi dan variasi-variasinya berdasarkan penelitian.

Beberapa antropog yang disebutkan Achmad F. Saifuddin (pengajar dan pakar antropologi di Universitas Indonesia) adalah mereka yang juga memiliki kontribusi bagi dunia antropologi sepanjang zaman di mana antropologi menjadi kajian yang signifikan dalam ilmu pengetahuan sosial, budaya, dan agama. Sebut saja di antaranya adalah R. Beals dan J. Hoijer (1954), Anthropology, C. Holmes (1963), Anthropology, M. Harris (1976), Man, Nature, and Culture, R. M. Keesing (1981), Perspective in Cultural Anthropology, J. Havilland (1991), Cultural Anthropology, P. Kottak (1994), Cultural Anthropology, C. Ember dan M. Ember (1996), Anthropology. ${ }^{1}$

Implikasi dari belajar antropologi, manusia dapat turut berkontribusi tentang bagaimana dia mengimplikasikan (melibatkan) dirinya dalam lingkungan sosial yang mikro dan makro, lingkungan keagamaan, lingkungan kerja, lingkungan pendidikan, lingkungan kebudayaan, dan lingkungan kebangsaan. Antropologi menggiring kita untuk memasuki tiga dunia yaitu dunia lampau (historisisme), dunia sekarang (prosesisme), dan dunia yang akan datang (eskatologisme).

\section{Metode Penelitian}

Pada penelitian ini, penulis atau peneliti menggunakan pendekatan atau metode kualitatif untuk memperoleh data yang valid guna membangun sebuah teori yang berkaitan dengan tema atau pokok penelitian. Metode kualitatif yang dimaksud adalah mengkaji dan mengelaborasi setiap sumber, informasi dan data-data yang diperoleh dari pustaka.

\section{Hasil dan Pembahasan}

\section{Pemahaman Tentang Antropologi}

Memahami antropologi bisa dilakukan dengan berbagai cara. Setiap bentuk pemikiran dalam pengkajiannya terhadap antropologi selalu melibatkan tiga hal: pertama, sejarah potensi humanitas; kedua, proses memahami keberlangsungan hayati manusia; dan ketiga, memahami (memikirkan) masa depan dari ke-hayati-an manusia.

Pertama, sejarah potensi humanitas berbicara tentang apa saja yang telah dilakukan manusia di masa lampau yang dilihat dari aspek fisik, moralitas, spiritual, tanggung jawab, dan kontribusinya bagi keberlangsungan hayati. Dari sejarah potensi humanitas, kita dapat belajar bagaimana melihat kekayaan potensi manusia yang dapat diwariskan ke generasi sekarang ini.

Kedua, proses keberlangsungan hayati manusia berbicara mengenai kondisi zaman sekarang yang dapat diamati sebagai bagian dari pembelajaran diri, pembenahan diri, pengembangan diri, dan pengaruh diri bagi orang lain dalam wilayah sosial, budaya,

1 Achmad F. Saifuddin, Logika Antropologi: Suatu Percakapan [Imajiner] Mengenai Dasar Paradigma (Jakarta: Prenadamedia Group, 2015). 
pekerjaan, dan agama. Apa yang dapat dinilai di zaman sekarang adalah tuntutan naluriah humanitas seseorang. Di wilayah sosial, manusia membangun relasi. Relasi tersebut dapat terbentuk melalui kesamaan suku, bahasa, adat, pekerjaan, dan agama. Di samping itu, relasi dapat terbentuk pula dari "rasa kemanusiaan" dan "rasa require [membutuhkan]". Tujuannya adalah membentuk sebuah relasi bagi pengembangan, pengaruh, pembenahan, dan pembelajaran diri.

Di wilayah budaya (adat istiadat, pemikiran, kebiasaan) manusia melakukan kebiasaan secara bersama-sama yang diatur secara sistematis, kasuistik, dan konsensus.Dengan mengamati, melakukan, dan menyimpulkan hasil pengamatan tentang budaya maka manusia dapat menentukan apakah ada yang dapat dijadikan sebagai pembelajaran diri, pembenahan diri, pengembangan diri, dan pengaruh diri bagi orang lain.

Di wilayah pekerjaan manusia bekerja untuk mempertahankan hidup (diri), yang berimbas pada konsep dan cara berpikir manusia tentang bagaimana ia dapat menikmati kehidupan yang layak dan menyenangkan, kehidupan yang damai, tentram, dan nyaman, kehidupan yang sejahtera dan bahagia. Semuanya dapat dialami melalui hasil pekerjaan. Sejalan dengan pemikiran ini, bekerja adalah naluriah manusia. Tanpa bekerja, potensi internalnya tidak akan menjadi sebuah upaya yang menghasilkan sesuatu melainkan menghasilkan kemerosotan hidup dan bahkan kematian (tidak dapat menikmati hidup lebih lama). Secara prinsipil, bekerja adalah kewajiban semua orang tanpa terkecuali.

Di wilayah agama manusia memahami dan menerapkan nilai-nilai ajaran agamanya, kitab sucinya, dan pandangan-pandangan terhadap agama dan kitab suci itu sendiri. Ada banyak peluang yang terbuka dan longgar dari proses memahami dan menerapkan nilai-nilai ajaran agamanya, kitab sucinya, dan pandangan-pandangan terhadap agama dan kitab suci. Relasi inter-religi menjadi rusak. Relasi sosio-kultural juga ikut menjadi terganggu. Relasi-relasi lainnya juga demikian. Ada cukup banyak relasi yang terganggu, tercemar, terluka, dan rusak akibat dari proses memahami nilainilai ajaran agamanya, kitab sucinya, dan pandangan-pandangan terhadap agama dan kitab suci. Namun, seyogianya manusia dapat memahami secara bijak tentang duduk persoalan yang tercipta atau terbentuk dari serangkaian kekeliruan atau sentimen yang mengatasnamakan agama atau kitab suci.

Ketiga, masa depan dari ke-hayati-an manusia berbicara mengenai langkahlangkah antisipatif dan kontributif terkait dengan apa yang akan dicapai di masa depan dan apa yang akan diwariskan di masa depan kepada generasi berikutnya. Kontribusi yang dimaksudkan di sini adalah berbagai karya-karya kemanusiaan, moralitas, spiritualitas, religiositas, kredibilitas, dan loyalitas.

Itu sebabnya, antropologi menata kehidupan manusia dan bukan hanya sampai pada tataran teori. Praktik hidup harus diwujudkan dalam sikap hidup. Sejatinya, antropologi berbicara tentang respons manusia terhadap kehidupan dan keragaman di dalamnya, dan respons manusia terhadap alam semesta (lingkungan) di mana ia tinggal. Sederhananya, antropologi terkait erat dengan perilaku sosial, fungsional, struktural, intepretatif atas situasi dan kondisi kehidupan manusia baik dalam lingkungan terkecil (keluarga), lingkungan medium (lingkungan masyarakat di mana ia tinggal), dan lingkungan makro (terbesar) yakni bangsa dan negara.

\section{Natur Antropologi}

Kajian tentang antropologi sebagaimana yang dibahas oleh para pakar, telah melahirkan berbagai dampak dan terobosan. Terobosan-erobosan telah memberikan 
sumbangsih pemikiran dan keberlangsungan konten-konten dan konteks-kontesk antropologi itu sendiri. Dalam pengamatan saya, natur antropologi memuat tentang pokok-pokok penting yang akan memandu setiap orang ketika belajar tentang bagaimana manusia dilihat dari perspektif biologis [fisik], sosio-religi, budaya, dan sebagainya. Pokok-pokok penting tersebut adalah: pertama, Substansi; kedua, Tujuan Eskatologis; ketiga, Pendekatan; keempat; Implikasi; dan kelima, Aplikasi.

Pertama, substansi antropologi dilihat dari objek yang diamati dan diasesmen. Manusia adalah makhluk sosial yang memiliki potensi-potensi visibel dan invisibel. Dalam perkembangannya, manusia telah menciptakan berbagai budaya dan karyakarya yang luar biasa. Berbagai kesulitan telah ditempuh dan ditembusi oleh manusia untuk menghasilkan sesuatu yang bermanfaat bagi sesamanya maupun merusak [menghancurkan] sesamanya. Dengan demikian, substansi antropologi menyuguhkan objek penelitian humanitas dengan kekayaan diri manusia itu sendiri (misalnya potensi fisik, potensi logika, potensi linguistik [komunikasi], potensi moral, dan potensi spiritual).

Potensi fisik berbicara tentang kekuatan, daya, dan upaya manusia untuk mempertahankan hidup. Semua antropolog memiliki pontesi ini. Mereka yang mengemukakan berbagai teori dan penemuan di bidang ini, selalu dalam kategori "mempertahankan hidup". Semua manusia, tanpa terkecuali, memiliki pontensi fisik. Sebabnya adalah manusia adalah makhluk yang hidup, memiliki kekuatan untuk bertindak dan berkarya.

Potensi logika berbicara tentang hasil-hasil pemikiran. Pemikiran dituangkan dalam bentuk verbal (komunikasi, argumentasi) dan dokumentatif (buku, dan sebagainya). Potensi logika adalah potensi yang bisa menunjang segala sesuatu sesuai dengan kadarnya. Manusia yang adalah makhluk berpikir berupaya untuk berpikir bagi kelangsunga hayatinya. Ketika manusia gagal (atau malas) berpikir tentang prosesisme kehidupannya, maka ia akan kehilangan banyak kesempatan untuk menikmati hidup ini.

Potensi linguistik [komunikasi] berbicara tentang kemampuan manusia untuk menyampaikan (mengkomunikasikan) gagasan-gagasannya tentang kemanusiaan atau apa saja yang terkait dengan potensi fisik, logika, moral, dan spiritual. Potensi linguistik dapat menjadikan seseorang piawai dalam berkomunikasi (berkata-kata). Komunikasi yang menggunakan diksi terstruktur adalah sebuah kelebihan eksternal ynag ditempuh dan didapatkan dari sejumlah empiris sang komunikator. Linguistik itu perlu dan sangat perlu sebab itu merupakan jembatan pemahaman manusia antara penyampai pesan dan penerima (pendengar) pesan. Dunia linguistik adalah dunia yang signifikan. Potensi ini memiliki kesamaan dalam hal perwujudannya yakni dalam bentuk verbal (komunikasi, argumentasi) dan dokumentatif (buku, dan sebagainya).

Potensi moral berbicara tentang afeksi faktual sebagai akumulasi dari potensi fisik, potensi logika, dan linguistik. Moralitas terukur dari "tindakan nyata". Namun, tindakan nyata masih dapat berbentuk samar-samar atau dengan kata lain, moralitas manusia dapat berpotensi hipokrit. Lalu bagaimana kita dapat melihat totalitasnya? Caranya adalah perlu pengamatan secara konsisten yang mengasesmen pemikiran, perkataan, dan perilaku seseorang setiap hari atau prosesnya hidupnya dinilai secara kontinu. Namun, tugas kita adalah bukan untuk melulu menilai orang lain. Sebaliknya, kita dituntut untuk menilai juga diri kita sendiri sebelum "cermin hidup" dipapaskan kepada orang lain.

Potensi spiritual berbicara tentang relasi manusia dengan Sang Pencipta (bagi yang beragama), relasi manusia dengan "sesuatu yang lain" yang dipercaya, relasi manusia 
dalam konteks humanitas-misterius (sesuatu yang gaib) yang dipercaya. Spiritual lebih terarah kepada relasi yang tak tampak sedangkan moralitas adalah relasi yang tampak. Dunia yang tak tampak dikategorikan sebagai dunia spiritual. Manusia memiliki sebuah pemahaman tersendiri mengenai dunia ini. Antropologi dapat mencermati-meski tidak secara mendalam-persoalan ini yang dengannya, mayoritas manusia-manusia yang beragama seringkali membonceng gagasan spiritual untuk meraup berbagai keuntungan-misalnya perdukunan-yang disinyalir memberikan kemakmuran, kekayaan, ketenaran, kenamaan, dan sebagainya.

Kedua, tujuan eskatologis. Antropologi tidak hanya berbicara mengenai historisitas humanisme hayati dengan berbagai seluk beluknya, atau pula berbicara mengenai halhal kekinian dalam konteks yang lebih luas, melainkan juga memikirkan bagaimana masa depan humanisme hayati itu sendiri. Antropolog-antropolog juga mengusung berbagai teori prediksi, spekulasi, ramalan, analisis kontekstual yang bersifat futuristik. Hal ini dipandang sebagai bagian yang tidak terpisahkan dari hampir-atau bahkan totalitas-bidang keilmuan yang dipelajari manusia. Artinya, setiap yang kita pikirkan, pelajari, analisis, asesmen, hasilkan, jalani, lakukan, rangkumkan, selalu berorientasi pada masa depan. Tujuan eskatologis dari antropologi tidak hanya bersoal jawab dengan kerumitan-kerumitan paradigma, genetika, anatomi, dan lainnya, melainkan juga memikirkan implikasi eskatologis bagi keberlangsungan hayati yang diikat dengan prinsip-prinsip kemanusiaan yang sejati, sebagai upaya menyingkirkan sikap-sikap apatis-agamais, egoisme mayoritas, egoisme kitab suci, dan egoisme lainnya.

Ketiga, pendekatan. Mempelajari antropologi, membutuhkan berbagai pendekatan. Pendekatan yang digunakan adalah pendekatan fenomenologis, studi kasus, etnografi, ontologis humanisme terbatas, ontologis humanisme komparatif, dan lain sebagainya. Pendekatan-pendekatan tersebut dilakukan untuk memenuhi aspek-aspek objektivitas dan faktualisme dalam kajian-kajian historikal dan kontemporer (humanitas progresif dan humanitas eskatologis). Pendekatan yang dilakukan setidaknya merupakan data atau dokumen penting bagi natur antropologi.

Keempat, implikasi (keterlibatan [pengaruh]). Seyogianya, antropologi mengusung implikasi-implikasi logis bagi perkembangan dan keberlangsungan hayati manusia. Implikasi itu sendiri terdiri atas tiga hal: (1) implikasi dalam hal menjaga tatanan kemasyarakatan; (2) implikasi dalam hal menjaga tatanan bangsa dan negara; dan (3) implikasi dalam menjaga tatanan sebuah komunitas tertentu (agama, persekutuan, perhimpunan, kelompok, dan sebagainya). Implikasi dalam menjaga tatanan kemasyarakatan adalah dengan mengusung tema-tema humanisme yang relavan dan yang berdaya guna bagi perkembangan dan kemajuan nilai-nilai dan relasi kemanusiaan itu sendiri. Implikasi dalam hal menjaga tatanan bangsa dan negara adalah dengan mengusung tema-tema patriotisme, tanggung jawab warga negara, partisipasi (kontribusi) manusia dalam membangun bangsa dan negaranya. Implikasi dalam menjaga tatanan sebuah komunitas tertentu (agama, persekutuan, perhimpunan, kelompok, dan sebagainya) dengan mengusung tema-tema perdamaian, cinta kasih, gotong-royong, pendalaman doktrinal, relevansi moralitas, relevansi pewahyuan dengan kehidupan nyata, dan pokok-pokok lainnya yang sesuai dengan gagasan religiositas agama masing-masing.

Kelima, aplikasi. Seyogianya, setiap rumpun ilmu memiliki aplikasi, entah aplikasi faktual atau aplikasi eskatologis (yang berdampak di kemudian hari). Aplikasi antropologi seyogianya menjadikan manusia semakin mengenal dirinya dan lingkungannya. Tidak perlu muluk-muluk, manusia harus bisa menjadikan dirinya panutan, menampilkan karya-karya yang bermanfaat dan berguna bagi sesamanya dan 
mengantarkan orang lain pada pemahaman bahwa manusia itu memiliki tugas yang sangat penting bagi keberlangsungan hayati personal maupun komunal. Aplikasi merupakan bagian yang tak terpisahkan dari hayati humanitas kita. Pasalnya, dari aplikasi itu, dunia, negara, bangsa, pekerjaan, pendidikan, kesehatan, dan kerohanian dapat terbangun. Tidak berlebihan jika saya mengatakan bahwa "tanpa terkecuali, aplikasi antropologi seharusnya membangun manusia seutuhnya sesuai dengan koridornya masing-masing dan mengkonstruksikan gagasan-gagasan kemanusiaan, kebersamaan, kemajemukan, dan menampilkan karya-karya generalitas bagi kehidupan yang aman, damai, dan simbiosis-mutualis.

Berangkat dari elaborasi di atas, antropologi berbicara tentang pemahaman akan natur humanitas, potensi humanitas, dan tanggung jawabnya, baik kepada diri sendiri, kepada masyarakat dan lingkungan, dan kepada Tuhan (bagi kaum beragama). Natur, potensi, dan tanggung jawab manusia terwujudkan di dalam dan melalui lingkungan keluarga, lingkungan kerja, lingkungan pendidikan, lingkungan kebudayaan (kesukuan), lingkungan kemajemukan, dan lingkungan kebangsaan.

\section{Tiga Dunia Antropologi}

Antropologi mencakup pembahasan tiga dunia (konteks) yaitu historisisme, prosesisme, dan eskatologisme.

Historisisme memuat tentang bagaimana manusia (termasuk para antropolog) untuk menyelidiki, mengasesmen, menganalisis, dan mengambil kesimpulan dari berbagai hal yang terjadi di masa lampau terkait dengan objek penelitian tertentu. Kesimpulan yang diambil dikorelasikan dengan implikasi dan aplikasi (internal dan eksternal) dan bisa dilanjutkan dengan mengembangkan atau melaksanakan (mewujudkan) potensi fisik, potensi logika, potensi linguistik [komunikasi], potensi moral, dan potensi spiritual, sebagaimana yang telah saya jelaskan sebelumnya.

Antropologi historisisme mengamati empat hal yakni: (1) sejarah tentang perilaku humanitas yang mencakup perkembangan sosial tertentu (atau umum), budaya tertentu (atau umum), dan agama baik tertentu (atau umum) yang dikaji secara umum, singkat, sistematis, atau bersifat aksentuatif. Perkembangan sosial tertentu akan menjelaskan sedikit dari beberapa konteks sosial sebagai pendahuluan dan gambaran umum saja. Begitu pula dengan konteks lainnya. (2) pengamatan atas objek-objek penelitian tertentu yang mencakup humanitas, proses keberlangsungan hayati, implikasi-implikasi logis dari sebuah relasi sosial, budaya, dan agama pada kelompok masyarakat pada umumnya maupun pada khususnya. Konteks-konteks ini, hanya beberapa saja yang dapat disinggung dalam pokok bahasan antropologi dan jika memungkinkan, yang lainnya sedapat mungkin mendapat perhatian khusus untuk dijelaskan atau dijadikan bahan analogi pembelajaran yang bersifat faktual-aplikatif. (3) asesmen antisipatif-eskatologis yang mencakup tindakan-tindakan yang diambil untuk melakukan antisipasi yang bernatur masa depan. Dalam pokok bahasan antropologi, seseorang (atau kita) perlu memikirkan implikasi yang akan muncul atau yang akan kita lakukan, kita penuhi, kita selesaikan, kita lanjutkan, sebagai tindakan antisipatif. Tindakan ini bermuara pada keberlangsungan hayati manusia itu sendiri. Jika tidak memikirkan antisipasi di konteks kini, maka akan ada kendala-kendala, atau hambatan-hambatan, atau persoalan-persoalan yang dapat menyita waktu dan kesempatan. Dengan begitu, tujuannya adalah "mengolah masa depan"; dan (4) kontribusi manusia bagi proses humanitas zaman sekarang yang berdampak pada masa depan. Setiap rumpun ilmu, memiliki tendensi masing-masing. Namun, saya meyakini bahwa setiap rumpun ilmu memiliki natur kontributif. Dalam proses pemahaman 
sampai kepada aplikasinya, antara teori dan praktik menjadi satu kesatuan (terintegrasi) secara solid untuk mencapai cita-cita ilmu itu sendiri. Antropologi tak terkecuali. Kontribusi-kontribusi keilmuan telah mewarnai dunia manusia. Tidak hanya mewarnai-dari sisi negatif-tindakan merusak, mengganggu, menghancurkan, dan mencemarkan pola kehidupan manusia dan alam semesta juga menjadi topik yang "up to date" (terbaru) dan atraktif (attractive, menarik). Kontribusi antroplogi bergantung pada manusia itu sendiri. Serumit-rumitnya antropologi, haruslah tertuang dalam wujud kontribusinya bagi dunia dan kehidupan di dalamnya. Tanpanya, antroplogi menjadi kering dan kekurangan gizi moralitas, kemanusiaan, spiritual, dan kehidupan di masa mendatang.

Dunia yang kedua adalah prosesisme. Prosesisme merupakan paham yang mengkaji tentang bagaimana manusia melihat dunia sekarang, mengamati, menilai, dan mengambil kesimpulan dari seluruh proses kehidupan yang terjadi di lingkungan mikro maupun makro, baik relasi sosial, budaya, pendidikan, moralitas, spiritualitas, dan agama. Dalam pengamatan kita, selalu dibarengi dengan "pengambilan keputusan". Ibaratnya kita sedang meneliti diri kita, kehidupan kita, perilaku kita, dan apa yang akan terjadi di kemudian hari dari segala yang dilakukan oleh kita. Dalam pengamatan, penyelidikan, asesmen, melibatkan proses yang akan menentukan hasil akhirnya. Manusia memiliki natur asesmentatif (suka menilai) terhadap segala sesuatu. Jika demikian, maka konteks asesmentatif perlu menjadi bagian dari sikap akademis kita untuk mengamati, menyelidiki, menganalisis, mempertimbangkan, dan mengambil keputusan (perumusan data dan dokumen) terhadap objek-objek antropologi. Hasilnya akan membawa kita kepada konteks selanjutnya yaitu "eskatologisme" antropologi.

Dunia yang ketiga adalah eskatologisme. Eskatologisme membahas tentang bagaimana manusia melihat dunia sekarang dan memikirkan korelasi hayati dan implikasi dari seluruh perbuatan manusia di zaman sekarang terhadap tanggung jawab di masa mendatang. Dari apa yang dilakukan dalam dunia prosesisme, manusia dikategorikan "telah" bertanggung jawab atas sikap hidupnya di mana ia menjadi bagian dalam totalitas hayati dari masyarakat/lingkungan, bangsa dan negara. Akan tetapi, tentu ada bahaya yang dapat muncul di sini. Ada orang atau sekelompok orang yang mengamati dunia antropologi untuk tujuan negatif, misalnya ingin menghancurkan dan sebagainya. Pada faktanya, ada kelompok-kelompok tertentu yang ingin memusnahkan suku atau kelompok lain karena dikurung oleh ideologi atau ajaran agama yang sempit.

\section{Analogi Budaya-Budaya Dalam Konteks Moral}

Sebagaimana diketahui bahwa antropologi juga mempelajari budaya-budaya manusia maka dalam bagian ini, saya hendak menguraikan perbedaan budaya dalam konteks moral. Ruth Benedict dalam Patterns of Culture ${ }^{2}$ (1934) sebagaimana dikutip oleh James Rachels, mengamati bahwa "moralitas berbeda-beda dalam setiap masyarakat dan merupakan kesepahaman yang pas untuk kebiasaan-kebiasaan yang disetujui bersama." Berangkat dari pengamatan Benedict, maka deskripsi berikut ini mewakili apa yang diamati Benedict.

\section{Bagian $\mathbf{1}^{3}$}

2 Pola-pola [Corak-corak] Budaya.

3 Diambil dari buku James Rachels, Filsafat Moral, terj. A. Sudiarja (Yogyakarta: Kanisius, 2017), 42-43. Judul asli The Elements of Moral Philosophy, New York, McGraw-Hill Companies, 2003. 
Darius, Raja Persia zaman dahulu, tergoda oleh adanya keragaman budaya yang ditemukan dalam perjalanannya. Ia menemukan, misalnya, bahwa orang Callatia (salah satu suku bangsa India) biasanya memakan jenazah orang tuanya ketika mereka meninggal. Orang-orang Yunani, tentu saja tidak melakukan hal yang demikian itu mereka membakar jenazah orangtua yang meninggal dan menganggap api pembakaran itu sebagai cara alami dan yang cocok untuk istirahat mereka. Darius berpikir bahwa pemahaman yang canggih mengenai dunia harus meliputi juga penjelasan tentang perbedaan antara budaya-budaya seperti itu. Pada suatu hari, untuk menguji pelajaran ini, raja memanggil sejumlah orang Yunani yang kebetulan ada dalam lingkungan istana dan bertanya kepada mereka apakah mereka akan makan jenazah ayah mereka yang meninggal. Mereka terkejut, sebagaimana diduga oleh raja Darius, dan menjawab bahwa berapa pun dibayar mereka tak akan terbujuk untuk melakukan hal yang seperti itu. Kemudian Darius memanggil sejumlah orang Callatia, dan sementara orangorang Yunani itu ikut mendengar, ia bertanya kepada mereka apakah mereka akan membakar jenazah ayah mereka yang meninggal. Orang-orang Callatia itu merasa ngeri dan memohon agar raja Darius jangan pernah menyebut hal yang demikian itu.

Kisah yang diceritakan kembali oleh Herodotus dalam buku "Sejarah" ini, melukiskan suatu tema yang selalu akan kembali dalam literature ilmu sosial: kebudayaan yang berbeda mempunyai kode moral yang berbeda pula. Apa yang dianggap benar oleh satu kelompok mungkin justru menjijikkan bagi anggota dari kelompok lain, dan sebaliknya.

\section{Bagian II ${ }^{4}$}

Suku Eskimo merupakan suku yang terpencil dan sulit dihubungi. Jumlah mereka hanya sekitar 25.000, hidup dalam rumah-rumah yang kecil dan saling terpisah, tersebar di sepanjang perbatasan utara antara Amerika dan Greenland. Hingga awal abad ini, dunia luar hanya tahu sedikit tentang mereka. Kebiasaan orang-orang Eskimo ternyata sangat berbeda dari kebiasaan kita. Laki-laki sering mempunyai lebih dari satu istri, dan mereka memberikan istri mereka kepada tamu-tamu, menyediakan mereka pada waktu malam sebagai tanda keramahan.

Lebih lanjut dalam suatu komunitas, laki-laki yang dominan mungkin meminta dan memperoleh - layanan seks secara teratur dari istri-istri lelaki lainnya. Meskipun demikian, para wanita bebas untuk memutuskan hubungan-hubungan ini cukup dengan meninggalkan suami-suami mereka dan beralih dengan partner yang baru. Mereka bisa bebas kalau suami mereka yang terdahulu tidak mau direpotkan. Dalam segalanya kehidupan orang Eskimo mengikuti skema yang berubah-ubah sehingga sedikit sekali kesamaannya dengan apa yang bisa kita sebut perkawinan.

Tetapi bukan hanya kehidupan perkawinan dan praktik seksualnya saja yang berbeda. Orang-orang Eskimo tampaknya juga kurang hormat pada kehidupan manusia. Pembunuhan bayi (infanticide) misalnya, amat lazim. Knud Rasmussen, salah satu dari antara para peneliti awal yang amat terkenal melaporkan bahwa ia menjumpai seorang wanita yang melahirkan dua puluh anak tetapi membunuh sepuluh dari antara mereka tatkala lahir. Bayi perempuan terutama cenderung untuk dimusnahkan dan hal ini dilakukan cukup dengan persetujuan orangtuanya, tanpa ada stigma sosial berkenaan dengan itu. Orang-orang tua juga, ketika mereka menjadi terlalu lemah untuk menyumbang keluarga, ditinggalkan sendirian di tengah salju

\footnotetext{
${ }^{4}$ Diambil dari buku Rachels, Filsafat Moral, 43-44.
} 
sampai meninggal. Jadi dalam masyarakat ini, tampaknya rasa hormat terhadap kehidupan begitu kecil.

Kesimpulannya adalah bahwa dalam dunia antropologi-sebagaimana dalam dunia sosial dan moralitas-objeknya jelas: manusia (yang berbentuk personal dan komunal [suku, bangsa, negara]. Namun, tidak hanya berkutat (sibuk memikirkan) unsur biologis humanitas melainkan juga memikirkan aspek-aspek lain dari totalitas humanitas. Seperti yang tampak dalam perbedaan perspektif dari budaya-budaya suku atau kelompok tertentu, berikut ini saya mengutip ringkasan Rachels ${ }^{5}$ yang dapat dianggap sebagai bagian dari penelitian atau pokok bahasan antropologi (seluk-beluk humanitas termasuk budaya atau kebiasaan yang berkembang dan diyakini sebagai kebenaran):

1. Orang-orang Yunani percaya bahwa makan jenazah tidak bisa dibenarkan, sedang orang-orang Callatia justru percaya bahwa mereka harus makan jenazah.

2. Oleh karena itu, makan jenazah tidak benar dan tidak salah secara objektif. Hal ini hanyalah soal pandangan yang berbeda dari satu budaya ke budaya lain.

3. Orang Eskimo tidak merasa bersalah dengan pembunuhan bayi, sedang orang Amerika menganggapnya immoral.

4. Oleh karena itu, pembunuhan bayi tidak benar dan tidak salah secara objektif. Hal itu hanyalah soal pandangan yang berbeda dari satu budaya ke budaya lainnya.

Dengan melihat pada perbedaan konsep atau cara pandang dari masing-masing budaya, maka antropologi perlu mendalaminya sebagai catatan kekayaan intelektual yang ada pada antropologi itu sendiri.

\section{Konsep-Konsep Dasar Dan Signifikansi Antropologi}

Secara mendasar, manusia memiliki potensi. Membicarakan kajian sosiologi dan antropologi selalu terkait dengan implikasi dari potensi manusia. Semua rumpun ilmu, tanpa terkecuali, selalu melibatkan potensi manusia. Mengapa? Karena semua rumpun ilmu diamati, dianalisi, dipelajari, didalami, diteliti, ditemukan, dipublikan, dan diciptakan oleh manusia yang berpotensi. Artinya, dari potensi menghasilkan potensi.

Potensi manusia ada bermacam-macam. Potensi didukung oleh cara berpikir, merasa, menghayati, meyakini, kontemplasi, prediksi, spekulasi, analisis (pengkajian), dan kenekatan (bersikeras, terlalu berani, tidak berpikir panjang [tidak mempedulikan apa-apa]). Potensi manusia yang bermacam-macam itu diklasifikasikan berdasarkan situasi dan kondisinya: (1) potensi mempertahankan hidup (diri); (2) potensi mengembangkan; (3) potensi memisahkan [memecahkan]; (4) potensi menyatukan; (5) potensi memelihara; (6) potensi menghancurkan; dan (7) potensi menciptakan sesuatu.

Potensi mempertahankan hidup adalah sebuah tanggung jawab hakiki dari setiap manusia. Kehidupan yang dimilikinya menuntut seseorang untuk bertanggung jawab secara moral, secara humanitas (diri dan orang lain), secara natur (pembawaan). Potensi mempertahankan diri merupakan pontensi paling tinggi dari semua potensi yang ada dalam diri manusia. Tak semua potensi yang dimiliki manusia selalu bermuara pada satu tujuan yaitu "mempertahankan hidup" bagi keberlangsungan hayatinya sendiri. Potensi mempertahankan hidup tidak bisa ditolak tetapi mutlak dijalankan.

\footnotetext{
${ }^{5}$ Rachels, Filsafat Moral, 48.
} 
Potensi mengembangkan adalah sebuah peluang manusia untuk lebih mengaplikasikan potensi-potensi yang ada dalam dirinya. Mengembangkan di sini adalah terkait dengan segala sesuatu yang membuat diri manusia itu bahagia, senang, sukacita, beruntung, kaya, kuat, sejahtera, dekat (relasi), mencapai cita-cita, berhikmat, terhormat, dihargai, pintar, cerdas, dan lain sebagainya. Manusia yang berpotensi mempertahankan hidup adalah mereka yang juga memiliki potensi untuk mengembangkan potensi-potensi internal.

Potensi memisahkan [memecahkan] adalah potensi positif dan negatif. Potensi positif berarti seseorang mampu untuk memisahkan antara yang primer dan sekunder dalam konteks kebaikan, keberlangsungan hayati; memisahkan antara yang baik dan jahat; memecahkan berbagai persoalan yang terkait dengan bagaimana manusia harusnya menyikapi hal-hal tertentu yang terjadi dalam kehidupannya. Potensi negatif berarti seseorang mampu memisahkan persahabatan yang sejati dengan cara-cara yang licik dan melampaui batas kemanusiaan; memisahkan hubungan antara yang satu dengan lain dengan cara fitnah atau provokasi; memecahkan persoalan bagaimana menjatuhkan lawan politik dengan cara "black campaign" dan menghalalkan segala cara meski cara-cara tersebut bertentangan dengan nilai-nilai normatif dan moralitas bahkan agama sekalipun.

Potensi menyatukan adalah adalah potensi positif dan negatif. Potensi positif berarti seseorang mampu menyatukan berbagai kekuatan untuk melawan musuh; mampu menyatukan berbagai perbedaan pendapat, kultur, agama, sosial, adat, dan sebagainya; mampu menyatukan hal-hal yang baik untuk kemudian dipublikasikan secara lokal, masiv, dan global. Potensi negatif berarti seseorang mampu menyatukan berbagai kekuatan jahat untuk melawan kebenaran; menyatukan hal-hal jahat untuk menjatuhkan orang lain atau bahkan memusnahkan orang lain.

Potensi memelihara adalah potensi di mana manusia berhak memelihara apa yang ada pada dirinya, pada lingkungan, dan pada orang lain. Pada dirinya adalah segala sesuatu yang menunjang keberlangsungan hayatinya, keberlangsungan relasinya dengan orang lain, atau yang lebih khusus lagi keberlangsungan relasinya dengan Tuhan (bagi kaum beragama). Pada lingkungan adalah bahwa manusia berhak memelihara (sebagai kesadaran internal) lingkungan (alam semesta) di mana ia tinggal atau berada. Kesadaran ini berimplikasi kepada keamanan, kesejahteraan, dan nyaman. Kita mungkin pernah melihat bagaimana lingkungan menjadi rusak akibat ulah manusia. Sebut saja penebangan hutan secara ilegal dan pembuangan sampah di sungai. Pada orang lain adalah bahwa seseorang berhak memelihara jalinan hubungan yang bersifat tetap (mengikat) maupun bersifat tidak tetap (tidak mengikat).

Potensi menghancurkan adalah potensi positif dan negatif. Potensi positif berarti seseorang mampu menghancurkan sesuatu yang dipandang dapat dihancurkan. Penghancuran ini berbicara mengenai sesuatu yang berbentuk fisik, karakter, dan pemikiran. Fisik terkait dengan manusia dan alam semesta dan segala isinya (di luar manusia). Karakter terkait dengan bagaimana karakter seseorang dibentuk sedemikian rupa untuk menghancurkan orang lain. Pemikiran terkait dengan bagaimana pengaruh yang intens terhadap seseorang dan kemudian cara atau pola berpikirnya menjadi terkontaminasi dengan pemikiran-pemikiran yang bersubstansi menghancurkan tatanan kehidupan, moralitas, dan relasi antara sesama. Kasus-kasus seperti ini sering terjadi.Di sisilain, potensi menghancurkan dapat bernaturpositif seperti menghancurkan kekuatan atau implikasi kejahatandan tindakan-tindakan amoral yangmerajalela di dalamkomunitas mikro (keluarga) dan makro (masyarakat atau bangsa). 
Potensi menciptakan sesuatu adalah potensi imajinatif dan eskatologis. Menciptakan sesuatu adalah bagian dari natur humanitas seseorang. Menciptakan berbagai hal tentu dapat bermanfaat bagi diri sendiri, orang lain, dan lingkungan (alam). Namun tetap terbuka peluang bagi manusia untuk menciptakan sesuatu yang dapat merusak tatanan hayati, tatanan moralitas, tatanan spiritualitas, tatanan masyarakat, dan tatanan alam semesta.

Memang, potensi manusia berimplikasi kepada dua kutub: positif dan negatif. Selalu terbuka peluang (kesempatan) bagi manusia untuk dapat melakukan hal-hal yang positif maupun negatif. Ketika antropologi berbicara tentang pemahaman akan natur humanitas maka yang dapat kita pahami adalah bahwa manusia berpotensi menciptakan dan menghasilkan segala sesuatu; manusia memiliki berbagai kelebihan untuk menata hidupnya, mempertahankan hidupnya, dan mencapai berbagai impian dan cita-citanya. Ketika antropologi berbicara tentang potensi humanitas, maka dapat disimpulkan bahwa manusia memiliki potensi yang berpeluang untuk menciptakan atau menghasilkan segala sesuatu yang baik, kurang baik, merugikan orang lain, menghancurkan orang lain, meresahkan orang lain, dan sebagainya, sebagaimana yang telah diuraikan di atas. Ketika antropologi berbicara tentang tanggung jawab humanitas, maka dapat disimpulkan bahwa secara komprehensif, responsibilitas (tanggung jawab) adalah bagian dan milik personal dari setiap umat manusia tanpa terkecuali. Mereka yang hidup (diberikan hidup) pasti responsibel atas dirinya sendiri, keluarganya, lingkungannya, kelompoknya, organisasinya, atau bangsa dan negaranya.

\section{Paradigma Antropologi}

Paradigma antropologi menjembatani level-level pemahaman tentang seluk-beluk humanitas dalam konteks-konteksnya. Paradigma (pola atau model) antropologi mengamati dan menganalisis serta mengambil kesimpulan ringkas tentang objek penelitian. Hasil atau kesimpulan tersebut dibuat dalam bentuk paradigmatik (kerangka rancangan) untuk masuk ke dalam konteks metodologinya. Berikut ini saya hendak menguraikan secara singkat tentang paradigma antropologi dalam enam konteks yaitu: Konteks Logikalisme, Konteks Sosial Agama, Konteks Budaya, Konteks Relasi, Konteks Konflik, dan Konteks Moralitas. Keenam konteks ini dapat memberikan korelasi-keilmuan antara dunia antropologi umum dengan dunia antropologi biblika.

\section{Konteks logikalisme}

Pola antropologi dalam konteks logikalisme berangkat dari dua aspek yakni aspek empirical dan aspek education. Aspek empirical adalah dasar dari semua pengetahuan yang dimiliki manusia, baik pengetahuan yang ditempuh melalui jalur formal dan informal. Empiris manusia sangatlah variatif dan bergantung pada kondisi geografis, situasi politik dan ekonomi, situasi suku dan bangsa, kondisi lingkungan keluarga, lingkungan masyarakat, dan kondisi organisasi atau kelompok.

Aspek empirikal dapat menciptakan berbagai karya tunggal maupun kolektif yang dapat diserap dalam dunia sosial dan budaya, serta agama. Konteks logikalisme sebenarnya mengedepankan karya dan inovasi manusia yang menyentuh wilayah humanitas, hayati, ekonomi, sosial, politik, agama, budaya, pekerjaan (bisnis), keluarga, dan sebagainya. Semua karya manusia selalu memiliki potensi untuk dapat terbagi atau dibagikan kepada berbagai jenis wilayah tadi. Dengan begitu, konteks antropologi logikalisme adalah manusia dengan potensi logikanya (pikirannya) dapat menemukan atau menciptakan berbagai terobosan yang dapat berguna bagi keberlangsungan hayati humanitas dan keberlangsungan pekerjaan dan usaha manusia itu sendiri. 
Aksentuasinya jelas bertumpu pada cara atau pola berpikir manusia untuk melihat kondisi terkini sebagai antisipasi bagi masa depan.

Oleh sebab itu, paradigma logikalisme haruslah memenuhi kriteria-kriteria logisfaktual-kontekstual ketika manusia menerapkannya. Kriteria-kriteria logis-faktualkontekstual adalah sebagai berikut: (a) Orientasi pemikiran (lokalisme) tertuju pada indikasi bahwa manusia harus mempertahankan hidupnya. (b) Orientasi pemikiran tertuju pada indikasi bahwa manusia harus menolong orang-orang terdekatnya. (c) Orientasi pemikiran tertuju pada indikasi bahwa manusia harus mengembangkan kualitas di mana ia bekerja. (d) Orientasi pemikiran tertuju pada indikasi bahwa manusia harus membantu sesama yang membutuhkan. (e) Orientasi pemikiran tertuju pada indikasi bahwa manusia harus berkontribusi bagi lingkungan di mana ia tinggal. (f) Orientasi pemikiran tertuju pada indikasi bahwa manusia harus berkontribusi bagi bangsa dan Negara, dan (g) Orientasi pemikiran tertuju pada indikasi bahwa manusia harus berkontribusi bagi agamanya.

\section{Konteks sosial agama}

Kedudukan manusia dalam kelompok sosial memiliki peran penting yang dengan sendirinya dapat memberikan kontribusi positif bagi keselarasan hayati. Paradigma antropologi sosial agama mencakup tiga hal: 1) menghayati dan mengamalkan ajaran agama; 2) pengajaran-pengajaran agama yang bermuatan moralitas, spiritualitas, penghargaan terhadap kehidupan, perlu diterapkan ke dalam lingkungan sosial yang mikro maupun makro; dan 3) berupaya menjembatani segala perbedaan dalam kelompok sosial (masyarakat) sehingga mencegah terjadinya konflik-konflik kepentingan atas nama agama.

\section{Konteks budaya}

Setiap masyarakat atau suku memiliki serangkaian budaya yang masih dipertahankan, dilestarikan, dan dikembangkan. Bahkan ada juga yang sedikit dimodifikasi sesuai konteks zaman (perkembangan). Paradigma budaya mencakup beberapa hal penting, di antaranya: 1) menghargai budaya lokal; 2) menghargai budaya orang lain; dan 3) turut serta dalam melestarikan dan mengembangkan budaya melalui pemikiran, tindakan, karya-karya tunggal maupun kolektif, dan kerja sama dengan berbagai pihak.

\section{Konteks relasi}

Hubungan yang tercipta di masyarakat adalah fakta di mana manusia adalah makhluk yang suka berelasi. Dalam banyak hal, relasi menjadi kunci bagi manusia untuk mengembangkan potensi diri dan bahkan potensi agama serta budaya. Relasi dapat dilakukan melalui komunikasi verbal person to person, tulisan (tanggapan atas masalah-masalah humanitas, dan sebagainya), dialog, musyawarah, dan percakapan lintas agama dan budaya. Paradigma konteks relasi manusia dalam kelompok sosial mikro dan makro mencakup lima hal: (a) membentuk pribadi melalui relasi dengan orang-orang terdekat; (b) membentuk pribadi melalui relasi dengan lingkungan masyarakat di mana ia tinggal; (c) mengedepankan sikap toleransi (menghargai dan menghormati) di dalam beragama konteks perbedaan; (d) mencegah konflik-koflik relasi yang bisa muncul akibat adanya perbedaan agama dan keyakinan; dan (e) turut menciptakan relasi yang baik dengan pemerintah dan pemuka agama dalam mengedepankan kehidupan yang harmonis, cinta damai, gotong royong dan mengasihi.

\section{Konteks konflik}

Peradaban (kebudayaan, dsb) manusia semakin maju. Tetapi konflik tetap saja masih terjadi. Konflik yang paling menyita perhatian adalah konflik agama. Secara substansial agama mendidik penganutnya untuk mencintai perdamaian, mencintai 
sesama dalam arti khusus, mencintai alam (lingkungan), dan mencintai/mengasihi Tuhan yang dipercayai. Akan tetapi, sejak dulu, agama sering dijadikan alat untuk tujuan politik dan ekonomi. Konflik-konflik yang terjadi sering melebar ke mana-mana. Konflik antar agama memang sulit dibendung sebab ini terkait dengan berbagai gagasan kitab suci yang menjadi acuan atau landasan kebenaran dari masing-masing agama. Tidak hanya itu, mencuatnya konflik berbasis agama telah merambah ke dunia politik, ekonomi, budaya, pekerjaan, pemerintahan, yang menjadi sasaran empuk bagi masuknya ideologi-ideologi separatis dan radikal.

Paradigma penanganan konflik setidaknya mengusung beberapa cara yakni: 1) menyelidiki duduk persoalan; 2) tidak menggabungkan setiap konflik dengan melakukan generalisasi seperti agama, suku, ras, budaya, dan sebagainya (misalnya ketika Donald Trump mengakui bahwa Yerusalem adalah ibukota Israel maka manusia berlomba-lomba membenci orang Amerika, padahal mungkin tidak semua yang setuju dengan gagasan dan keputusan Trump); 3) mengikutsertakan atau mengutamakan penanganan konflik oleh pihak-pihak yang berwenang untuk melerai, menyelesaikan, dan melakukan tindakan hukum; 4) tidak menyuarakan gagasan-gagasan separatis dan radikal dengan membonceng teks-teks kitab suci sebagai dasar untuk membuka peluang konflik agama dan kemanusiaan yang dapat berdampak meluas ke berbagai wilayah.

\section{Konteks moralitas}

Paradigma memahami konteks moralitas sebenarnya merupakan hal umum di masyarakat. Pasalnya, moralitas adalah sesuatu yang tampak di permukaan proses hayati humanitas itu sendiri di mana kita ada di dalam proses tersebut. Moralitas tidak hanya berbicara mengenai totalitas tutur kata, sikap, perilaku, relasi, tetapi juga berbicara mengenai bagaimana komitmen dan konsistensi seseorang dalam melakukan dan menyebarluaskan perbuatan dan gagasan-gagasan yang baik di masyarakat, keluarga, organisasi, dan sebagainya.

Paradigma kunci dalam menggeluti dunia moralitas mencakup dua hal yaitu: pertama, mencari titik persamaan persepsi tentang apa yang dinilai baik dan apa yang dinilai buruk dalam satu konstitusi (penyusunan, pembentukan) logika (cara berpikir) yang berpotensi masiv dan diterima secara umum; kedua, menentukan agenda dasar dari moralitas yang disepakati bersama untuk dikembangkan ke dalam berbagai strata sosial.

\section{Metodologi Dan Pendekatan-Pendekatan}

Berbicara tentang metodologi tidak lepas dari pendekatan-pendekatan sebagian bagian integralnya. Secara umum yang diterima bahwa metodologi penelitian ada tiga macam: metodologi kualitatif, metodologi kuantitatif, dan metodologi campuran (gabungan) kualitatif dan kuantitatif.6 Menurut Newman dan Benz, pendekatan kualitatif dan kuantitatif seharusnya tidak dipandang sebagai antitesis atau dikotomi yang saling bertentangan; keduanya hanya mempresentasikan hasil akhir yang berbeda, namun tetap dalam satu continuum (kesatuan). ${ }^{7}$ Menurut Creswell, "Perbedaan antara penelitian kualitatif (qualitative research) dan penelitian kuantitatif (quantitative research) sering kali dijelaskan berdasarkan bentuk-bentuknya yang menggunakan kata-kata (kualitatif) dan yang menggunakan angka-angka (kuantitatif),

${ }^{6}$ Lih. John W. Creswell, Research Design: Pendekatan Metode Kualitatif, Kuantitatif, dan Campuran, terj. Achmad Fawaid dan Rianayati K. Pancasari(Yogyakarya: Pustaka Pelajar, 2016), 3-4. Creswell adalah seorang profesor psikologi pendidikan di University of Nebraska-Lincoln.

${ }^{7}$ Creswell, Research Design, 4. 
atau berdasarkan pertanyaan-pertanyaan yang tertutup (hipotesis kuantitatif) dan yangterbuka (hipotesis kualitatif). Padahal, gradasi perbedaan antarkeduanya sebenarnya terletak pada asumsi filosofis dasar yang dibawa oleh peneliti ke dalam penelitiannya, jenis-jenis strategi penelitian yang digunakan peneliti sepanjang penelitiannya (seperti strategi eksperimen kuantitatif atau strategi studi kasus kualitatif), dan metode-metode spesifik yang diterapkan peneliti untuk melaksanakan strategi-strategi ini (seperti pengumpulan data secara kuantitatif dalam bentuk instrumen versus pengumpulan data secara kualitatif melalui observasi lapangan)." ${ }^{8}$

Penelitian di bidang antropologi membuka peluang kepada para peneliti untuk menggagas berbagai materi-materi penelitian dalam kaitannya dengan antropologi seperti sosial, budaya, dan agama. Pula komunikasi dan relasi di dalam kelompok masyarakat dan pengaruhnya bagi kesinambungan hayati humanitas. Untuk mendalami dunia metodologi, Creswell menyebutkan tiga komponen penting dalam rancangan penelitian yaitu: (1) asumsi-asumsi pandangan dunia filosofis yang mereka bawa ke dalam penelitiannya; (2) rancangan penelitian yang berhubungan dengan pandangan dunia tersebut, dan (3) metode-metode atau prosedur-prosedur penelitian spesifik yang dapat menerjemahkan pendekatan tersebut ke dalam praktik. ${ }^{9}$

Creswell membagi empat jenis pandangan dunia (worldwiew) ${ }^{10}$ yang dapat menjadi acuan dasar dan evolusi penelitian antropologi:

\begin{tabular}{|c|c|}
\hline Post-Positivisme & Konstruktivisme \\
\hline $\begin{array}{ll}\text { - } & \text { Determinisme } \\
\text { - } & \text { Reduksionisme } \\
& \text { (menyederhanakan } \\
& \text { supaya tidak sulit) } \\
\text { - } & \text { Pengamatan dan } \\
& \text { pengukuran empiris } \\
\text { - } & \text { Verifikasi teori }\end{array}$ & $\begin{array}{l}\text { - } \text { Pemahaman } \\
\text { - Makna yang beragam dari } \\
\text { partisipan } \\
\text { - Konstruksi sosial dan } \\
\text { historis } \\
\text { - Penciptaan teori }\end{array}$ \\
\hline Transformatif & Pragmatisme \\
\hline $\begin{array}{l}\text { - Politis } \\
\text { - Berorientasi kekuasaan } \\
\text { dan keadilan } \\
\text { - Kolaboratif } \\
\text { - Berorientasi perubahan }\end{array}$ & $\begin{array}{l}\text { - } \text { Akibat-akibat tindakan } \\
\text { - } \text { Berpusat pada masalah } \\
\text { - } \text { Pluralistik } \\
\text { dunia nyata } \\
\text { dunorientasi pada praktik }\end{array}$ \\
\hline
\end{tabular}

Pendekatan yang saya sebutkan berikut ini adalah bagian dari metodologi penelitian kualitatif. Sebagaimana yang dijelaskan oleh John W. Creswell, pendekatan kualitatif terdiri atas lima yakni naratif, fenomenologis, grounded theory, etnografi, dan studi kasus. Pendekatan-pendekatan yang digunakan dalam penelilitian antropologi, terdiri atas: (1) Fenomenologis, (2) Studi Kasus, (3) Etnografi, (4) Ontologis Humanisme Terbatas, (5) Ontologis Humanisme Komparatif, (6) Ontologisme Fenomenologis; (7) Pendekatan Empirikal-Komparatif; (8) Pendekatan EmpirikalReligiositas; (9) Pendekatan Relasi-Kultural; dan (10) Pendekatan AnalisisKonstruktivistik. Metodologi antropolologi berkaitan erat dengan metodologi sosial,

\footnotetext{
${ }^{8}$ Creswell, Research Design, 4.

${ }^{9}$ Creswell, Research Design, 6.

10 Creswell, Research Design, 8.
} 
budaya, dan agama karena keempat bidang ini saling terkait dan kadang memiliki objek yang sama.

1. Pendekatan fenomenologis. Pendekatan ini menjelaskan penarikan kesimpulan dari pengamatan (yang dilakukan) terhadap sejumlah objek penelitian yang berfokus pada fenomena yang terjadi dalam kehidupan dan pengalaman manusia. Kesimpulan yang diambil dapat dijadikan sebagai "model", "pedoman' atau "gambaran", bagi konteks yang lebih luas sebagai pemaknaan general tatkala kesimpulan tersebut berkorelasi (terhubung) dengan konteks-konteks yang lain.

2. Studi kasus. Dalam dunia antropologi studi kasus terkorelasi dengan penelitian sosial pada umumnya. Artinya, dalam tataran penelitian, seseorang dapat menggunakan metodologi kualitatif dengan pendekatan studi kasus. Pendekatan ini lebih mengarah kepada spesifikasi tertentu dari sebuah kasus yang terjadi di masyarakat (sosial), agama, budaya, dan sebagainya. Pendekatan studi kasus mengedepankan wawancara dan pengumpulan data lapangan terkait dengan objek yang diteliti. Peneliti perlu melakukan observasi dan penggalian data dari kasus yang sedang diteliti. Pengumpulan data perlu menekankan objektivitas fakta. Creswell dengan mengutip Yin, menyebutkan bahwa penelitian studi kasus mencakup studi tentang suatu kasus dalam kehidupan nyata, dalam konteks kontemporer. Menurut Creswell, peneliti mengeksplorasi kehidupan nyata, sistem terbatas kontemporer atau beragam sistem terbatas melalui pengumpulan data yang detail dan mendalam yang melibatkan beragam sumber informasi dan melaporkan deskripsi kasus dan tema kasus. ${ }^{11}$ Tiga variasi dari studi kasus yaitu: 1) studi kasus instrumental tunggal, 2) studi kasus kolektif, dan 3) studi kasus intrinsik (berfokus pada kasus itu sendiri [terkandung di dalamnya]).

3. Pendekatan etnografi. Menurut Creswell pendekatan ini berfokus pada kelompok yang mempunyai kebudayaan yang sama. Etnografi mendeskripsikan dan menafsirkan pola yang sama dari nilai, perilaku, keyakinan, dan bahasa dari suatu kelompok berkebudayaan sama. ${ }^{12}$ Jadi, etnografi menitikberatkan pada pengamatan budaya dari kelompok-kelompok manusia terkait dengan perilaku, keyakinan, dan bahasa yang digunakan, berproses, dan berkembang dalam kelompok-kelompok tersebut. Creswell menyebutkan dua bentuk etnografi yang populer: etnografi realis dan etnografi kritis. Etnografis realis adalah pendekatan tradisional yang digunakan oleh para antropolog kebudayaan; suatu laporan objektif tentang situasi, biasanya ditulis dalam sudut pandang orang ketiga dan melaporkan secara objektif informasi yang dipelajari dari para partisipan di suatu tempat. Etnografi kritis adalah para penulisnya (penelitinya) memperjuangkan emansipasi bagi kelompok masyarakat yang terpinggirkan (Thomas, 1993). Para peneliti berpikir politis yang berusaha, melalui riset, untuk menentang ketidaksetaraan dan dominasi. ${ }^{13}$

4. Pendekatan ontologis humanisme terbatas. Pendekatan ini menjelaskan pemahaman terhadap humanitas yang menyentuh hal-hal esensial realitas (kenyataan) dan hakikat hidup manusia dalam satu kelompok sosial tertentu. Terbatas karena hanya mengamati salah satu kelompok masyarakat. Dengan kata lain, ontologisme humanisme adalah sebuah paham yang berbicara dan menyelidiki tentang eksistensi dari kelompok masyarakat dalam kerangka menemukan kesimpulan dari antropologi

${ }^{11}$ John W. Creswell, Penelitian Kualitatif dan Desain Riset. Edisi 3 (Yogyakarta: Pustaka Pelajar, 2015).

12 Creswell, Penelitian Kualitatif dan Desain Riset.

${ }^{13}$ Creswell, Penelitian Kualitatif dan Desain Riset. 
tentang (1) potensi mempertahankan hidup (diri); (2) potensi mengembangkan; (3) potensi memisahkan [memecahkan]; (4) potensi menyatukan; (5) potensi memelihara; (6) potensi menghancurkan; dan (7) potensi menciptakan sesuatu.

5. Pendekatan ontologis humanisme komparatif. Pendekatan ini adalah perluasan dari pendekatan ontologisme humanisme terbatas. Pada ontologis humanisme komparatif, dapat diselidiki dan disimpilkan potensi-potensi yang terjadi di beberapa kelompok masyarakat, budaya, dan sebagainya (sejauh yang dapat diamati).

6. Pendekatan Ontologisme Fenomenologis. Ontologisme adalah sebuah pemahaman dan penelitian yang menyentuh hal-hal esensial realitas (kenyataan) sesuatu (hakikat hidup) yang diteliti. Atau dengan kata lain, Ontologisme adalah sebuah paham yang berbicara dan menyelidiki tentang eksistensi dari sesuatu yang diteliti. Ontologisme fenomenologis berbicara tentang esensi dari sebuah fenomena (faktual [kekinian] atau historis) dari sebuah kelompok sosial dan agama yang juga mengamati fenomena budaya yang berkembang, diterapkan, atau yang telah hampir punah dalam masyarakat/suku tertentu. Menurut Creswell, studi fenomenologis mendeskripsikan pemaknaan umum dari sejumlah individu terhadap berbagai pengalaman hidup mereka terkait dengan konsep atau fenomena. Tujuan utama dari fenomenologi adalah untuk mereduksi pengalaman individu pada fenomena menjadi deskripsi tentang esensi atau intisari universal. ${ }^{14}$ Creswell menjelaskan, fenomenologi diakhiri dengan bagian deskriptif yang membahas esensi dari pengalaman yang dialami individu tersebut dengan melibatkan "apa" yang telah mereka alami dan "bagaimana" mereka mengalaminya. ${ }^{15}$ Ini bisa dilakukan dalam konteks antropologi, sosial, agama, dan budaya. Creswell menyebutkan dua tipe fenomenologi yakni: fenomenologi hermeneutik (diarahkan pada pengalaman hidup dan ditujukan untuk menafsirkan "teks" kehidupan) dan fenomenologi empiris, transendental, atau psikologis (berfokus pada deskripsi tentang pengalaman dari para partisipan). ${ }^{16}$

7. Pendekatan Empirikal-Komparatif. Pendekatan ini membicarakan tentang studi dan analisis pengalaman dari dua kelompok masyarakat atau lebih yang kemudian dikomparasikan untuk mencari titik kesamaan atau perbedaan atau tujuan tertentu yang ditetapkan peneliti antropologi. Pengamalan-pengalaman yang diteliti adalah pengalaman-pengalaman umum seperti kontribusi pada budaya, konflik antar warga, pilkada, dan sebagainya.

8. Pendekatan Empirikal-Religiositas. Pendekatan ini membicarakan tentang studi dan analisis pengalaman dari setiap orang atau kelompok agama tertentu untuk dijadikan pelajaran, teladan komunal, atau sebuah pengarahan kepada sikap dan pola hidup beragama yang baik.

9. Pendekatan Relasi-Kultural. Relasi dalam masyarakat tercipta dari berbagai aspek seperti aspek agama, suku, ras, budaya, kesamaan ideologi, warna kulit, dan lainnya. Pendekatan relasi budaya (cultural) perlu dilakukan ketika peneliti akan mencari data dan informasi terkait kondisi atau fenomena yang terjadi di salah satu kelompok masyarakat tertentu atau mengamati budaya dalam masyarakat tertentu.

10. Pendekatan Analisis-Konstruktivistik. Pendekatan ini mengamati dan menilai setiap objek penelitian didasarkan pada tahapan-tahapan penelitian. Istilah konstruktivistik menggambarkan proses tahapan-tahapan tersebut. Di sini, penelitian terhadap bidang antropologi, pendekatan ini dapat diterapkan. Peneliti melakukan

\footnotetext{
${ }^{14}$ Creswell, Penelitian Kualitatif dan Desain Riset.

15 Creswell, Penelitian Kualitatif dan Desain Riset.

${ }^{16}$ Creswell, Penelitian Kualitatif dan Desain Riset.
} 
analisis data dan dokumen yang terkumpul berdasarkan tahahan perkembangan sumber-sumber yang didapatkan. Artinya ada rentang waktu yang ditentukan untuk mendapatkan hasil penelitian antropologi.

\section{A. JENIS-JENIS ANTROPOLOGI}

Antropologi sebagaimana lazimnya mempelajari tentang manusia dan keluasan karya yang dihasilkan melalui pemikiran, relasi, perenungan, budaya, komunitas, ideologi, sistem kepercayaan, agama, memiliki beberapa bidang kajian (atau pembagian). Berikut adalah jenis-jenis antropologi yang dikemas secara ringkas.

\section{Antropologi biologis [fisik] (perkembangan humanitas)}

Secara natur, manusia adalah makhluk yang lahir dengan mengikuti proses yang telah diberikan Tuhan. Artinya, konteks bagaimana manusia tercipta dan kemudian terlahir dan jenis yang sama perlu dilihat dari berbagai perspektif. Meski ada pandangan yang menyatakan bahwa manusia berasal dari spesies kera, namun kita tidak melihat bagaimana proses kehamilan dari spesies kera tersebut dan melahirkan anak-anak mereka. Tidak ada bukti ilmiah tentang itu. Namun, manusia sebagaimana kita ada sekarang ini, memiliki kekuatan argumen dan dokumen yang menjadi landasan pijak bahwa manusia makhluk yang deferen dengan makhluk lainnya.

Bahwa manusia memiliki sifat-sifat (bawaan) yang melekat dan seragam. Pemahaman natural dari eksistensi manusia adalah merupakan pokok bahasan dari antropologi fisik (biologis). Di samping itu, ciri-ciri fisik manusia adalah ia memiliki emosi, perasaan, dan kehendak yang dikontrol oleh hati dan pikiran. Pemahaman yang komprehensif tentang natur fisik manusia membawa kita pada kesimpulan bahwa apa yang ada pada diri manusia bisa bermanfaat sekaligus menghancurkan sesamanya.

Antropologi fisik tidak hanya berbicara soal bagaimana proses terjadinya manusia dalam masa kehamilan di dalam rahim perempuan. Tidak pula hanya berbicara soal bagaimana perkembangan fisik, mental, karakter. Tetapi antropologi fisik juga berbicara tentang "potensi humanitas" yang tampak dalam totalitas proses kehidupannya dan berdampak pada banyak aspek. Meski aspek-aspek positif adalah sesuatu yang diinginkan, tetapi aspek-aspek negatif-seperti konflik antar agama, suku, ras, golongan, bahkan antar sesama (sama-sama) pemeluk agama itu sendiri, dapat saja terjadi dan sudah terjadi.

Antropologi fisik atau biologis berdampak pengetahuan manusia tentang bagaimana menghargai hidup sejak awal terciptanya di dalam rahim perempuan; bagaimana menghargai sesama yang berbeda keyakinan, berbeda suku, pandangan, ideologi, dan sebagainya. Nilai-nilai humanitas tak tergantikan dengan kesenangan semata. Apa yang dikerjakan selama proses hidup akan memberikan nilai tambah dan turut mengembangkan potensi humanitas dalam konteks yang lebih luas.

Proses terjadinya manusia (dari gen yang sama) menghasilkan substansi yang sama pula. Ketika ada teori yang menyatakan bahwa manusia berasal kera yang berevolusi menjadi manusia, maka tidak ada bukti apa pun yang mendukung gagasan tersebut apalagi proses sebagaimana yang tertuang dalam gambar-gambar di atas. Tidak pernah ada kera yang hamil lalu keluar manusia. Jika teori evolusi dianggap masuk akal, maka seharusnya ada dokumen pendukung bahwa memang manusia berevolusi dari kera, berapa lama proses evolusi dan sampai kapan bentuk manusia yang ada sekarang akan berubah lagi menjadi sesuatu yang lain. Segala sesuatu harus memenuhi dua kategori yaitu: argumen dan dokumen. Keduanya hanya juga memenuhi tiga unsur yaitu: terdefinisi, terkonteks dan terklasifikasi. 
Dengan demikian, antropologi fisik (biologis) mengisyaratkan sebuah gagasan bahwa manusia itu unik dan luar biasa, sehingga dalam keseluruhan proses kehidupan yang ditempuh, manusia-manusia dapat saling mengembangkan potensinya untuk menciptakan sumber-sumber hayati yang dapat memelihara alam semesta, kehidupan pribadi dan kelompok, serta kontinuitas hayati di masa depan sebagai warisan bagi generasi berikutnya. Antropologi fisik menghasilkan potensi-potensi seperti: (1) potensi mempertahankan diri (sebagai bagian dari sikap hidup); (2) potensi mengembangkan (mengembangkan bakat, talenta, dan kelebihan lainnya); (3) potensi memecahkan [memisahkan] (melakukan pembedaan setiap pokok masalah yang ada); (4) potensi menyatukan (menyatukan berbagai perbedaan pemikiran dan konsep, budaya, dan sebagainya); (5) potensi memelihara (memelihara hidup sendiri, dan hidup orang-orang yang dicintai, memelihara alam semesta [lingkungan] di mana kita tinggal); (6) potensi menciptakan sesuatu (mengembangkan kemampuan diri untuk berkarya bagi banyak orang).

\section{Antropologi Budaya}

Dalam perkembangannya, manusia dibentuk dengan budaya yang ada dalam kapasitas yang masih terbatas karena tidak semua budaya yang dapat diterima oleh manusia. Menurut Achmad F. Saifuddin antropologi budaya adalah mencari tahu dan memahami suatu kebudayaan berdasarkan pengetahuan, keyakinan, dan tafsiran orang-orang yang ia teliti terlebih dahulu. Seperti yang diungkapkan Clifford Geertz, "antropog berupaya memahami suatu masyarakat berdasarkan pemahaman warga masyarakat yang bersangkutan." ${ }^{17}$ Konsep "relasi” menjadi acuan dalam budaya. Tanpa sebuah relasi maka manusia tidak akan menghasilkan budaya.

\section{Antropologi Sosial Agama}

Agama adalah kumpulan masyarakat (sosial) yang memiliki konsep dan pemahaman yang sama yang diikat oleh sebuah kepercayaan bersifat historis, kitab suci, personalitas yang Agung dan ditakuti, dan lain sebagainya. Agama dan sosial adalah dua hal yang tak bisa dipisahkan. Agama berdiri karena adanya aspek sosial, dan sosial dapat bertahan dan berkembang karena adanya agama (sistem kepercayaan) yang dipertahankan, dijaga, dijalankan, dan diresapi.

Menurut Saifuddin, "agama secara tradisional dipandang sebagai kebudayaan. Pendekatan ini terkait dengan tujuan antropologi untuk melakukan eksplanasi dan analisis mengenai agama, sehingga memandang agama sebagai perangkat doktrin yang datang dari Tuhan tentulah tidak produktif bagi kepentingan analisis kehidupan masyarakat dan kebudayaan. Kita dapat menelusuri cara pandang ini mulai dari konsepsi analogi organic Herbert Spencer (1820-1903) yang membawa analogi biologi ke dalam dunia sosial dan kebudayaan. ${ }^{18}$ Bagi Clifford Geertz, agama adalah inti kebudayaan yang menjadi acuan bagi kehidupan manusia, yang menjadi pandangan penjelasan mengenai dari mana manusia berasal, untuk apa ia hidup di dunia, dan ke mana ia pergi setelah meninggal. ${ }^{19}$ Agama, secara khusus di Indonesia kadang menjadi penentu arah politik. Jiwa sosiologi (dan antropologi) di Indonesia kurang lebih merepresentasikan gagasan Karl Marx bahwa "agama adalah candu bagi masyarakat."

17 Achmad F. Saifuddin, Logika Antropologi: Suatu Percakapan [Imajiner] Mengenai Dasar Paradigma (Jakarta: Prenadamedia Group, 2015), 3.

18 Achmad Fedyani Saifuddin, sambutan "Agama dalam Pendekatan Sosial Budaya: Dari Positivism eke Konstruktivisme”, dalam H. M. Ridwan Lubis, Sosiologi Agama: Memahami Perkembangan Agama dan Interaksi Sosial (Jakarta: Prenadamedia Group, 2017), vi.

19 Saifuddin, sambutan "Agama dalam Pendekatan Sosial Budaya: Dari Positivism eke Konstruktivisme", dalam Lubis, Sosiologi Agama, vi. 
Gagasan Marx memiliki dua implikasi: pertama, implikasi positif. Artinya, ketika masyarakat mengalami penindasan, tidak mendapat perlakukan yang layak dari dunia (pemerintah), kehilangan perasaan hidup, maka agama menjadi penyembuh luka-luka batin dan menawarkan kedamaian dan kesabaran. Masyarakat menjadi nyaman ketika agama berhasil men-"candu"-i mereka; kedua, implikasi negatif. Misalnya ketika masyarakat memasuki pesta demokrasi, isu agama akan seketika menjadi candu yang dapat membius penganut agama tertentu untuk menyatakan sikap protes, ketidaksetujuan, dan kebencian kepada mereka yang berbeda agama dengannya. Dan itu terjadi di Indonesia.

Memahami agama memiliki beberapa aspek yaitu: pertama, aspek pengajaran; kedua, aspek tafsiran teologis; ketiga, aspek fenomenologis; keempat; aspek relasional; kelima; aspek pemahaman; keenam, aspek ritual; ketujuh, aspek cita-cita. Semua aspek ini dapat terjadi dan berkembang dalam kelompok sosial. Aspek pengajaran berbicara tentang bagaimana manusia mengimplementasikan ajaran-ajaran Kitab Suci dalam relasinya dengan Sang Pencipta dan sesamanya. Pengajaran-pengajaran agama dalam berkembang menjadi perekat sekaligus pemisah dalam konteks relasi antar agama dan sosial masyarakat yanga lebih masiv. Aspek tafsiran teologis sering memunculkan berbagai spekulasi pemikiran yang cenderung menyesatkan. Akan tetapi, gagasan tafsiran teologis perlu dikumandangkan asalkan tidak melenceng dari maksud asli Kitab Suci. Memang sulit merealisasikannya namun hal ini sangat perlu bagi kesinambungan keimanan pemeluk agama masing-masing. Aspek fenomenologis diwujudkan dalam sejumlah empiris penganut agama yang mengulang berbagai fenomena yang terjadi di masa lampau. Tetapi, ada bahaya-bahaya yang dapat muncul ke permukaan ketika perubahan beradaban agama telah begitu terbuka bagi ilmu pengetahuan dan teknologi. Aspek relasional adalah hal-hal praktis yang dapat dipahami secara rasional tanpa memerlukan tafsiran teologis. Aspek pemahaman adalah aspek dasar bagi setiap orang beragama dalam mengkaji dan mengaplikasikan ajaran-ajaran dalam Kitab Suci. Aspek ritual merupakan aplikasi dari pemahaman keagamaan yang tertuang dalam bentuk ibadah, sembahyang, doa, dan sebagainya. Aspek cita-cita adalah perwujudan harapan agama-agama akan masa depan yang lebih baik. Apa yang dilakukan di masa kini dengan berangkat pada peristiwa historis dijadikan sebagai wacana (pemikiran) bahwa ajaran-ajaran agamanya tetap menjadi prioritas iman dan pemikiran dalam membentuk manusia menjadi berkarakter baik dan relasional.

Orang yang beragama secara prinsipil memiliki beberapa kelompok. Ada yang memahami agama secara artifisial (positif dan negatif). Ada yang memahaminya secara parsial (positif dan negatif). Ada yang memahaminya secara historis-radikal. Ada yang memahaminya secara historis-teologis. Ada yang memahaminya secara historis-aplikatif. Ada yang memahaminya secara harfiah. Ada yang memahaminya secara maknawi-relasional-humanis. Berangkat dari pemahaman-pemahaman tersebut, maka muncullah berbagai denominasi dalam agama itu sendiri. Secara hakiki agama dibentuk oleh beberapa faktor: pertama, faktor pewahyuan; kedua, faktor alam (interpretatif terhadap kondisi alam); ketiga, kesamaan ritual; keempat, faktor kesemaan ideologi; kelima, faktor kesamaan lokus, budaya, bahasa. Ketika kita melihat dalam satu agama terdiri atas berbagai suku, ras, dan golongan, serta kedudukan, maka faktor-faktor tersebutlah yang melatarbelakanginya. Franz Magnis Suseno menjelaskan, dalam tulisannya Karl Marx menyatakan bahwa pada dasarnya manusia yang membuat agama, bukan agama yang membuat manusia. Agama adalah perealisasian hakikat manusia dalam angan-angan saja, jadi tanda bahwa manusia 
justru belum berhasil merealisasikan hakikatnya. Agama adalah tanda keterasingan dari dirinya sendiri. ${ }^{20}$

Marx benar pada tataran fakta bahwa manusialah yang membuat agama, tetapi secara substansi bukan manusia yang membuat agama. Agama terbentuk dari sesuatu di luar manusia. Tanpa itu, manusia tak dapat menafsirkan sesuatu itu bagi dirinya sendiri. Tuhan sendiri yang memungkinkan manusia menafsir apa yang Tuhan berikan yang dengan demikian, agama, dalam konteks yang lebih resmi (dapat dipercaya dan diyakini oleh banyak orang atau kelompok).

Berangkat dari hal-hal tersebut, antropologi sosial agama berbicara mengenai tujuh hal yakni:

Pertama, manusia yang bersosial terikat dengan sistem agama yang dianutnya. Aspek-aspek normatif, moralitas, iman, ibadat, dan sebagainya, semuanya diatur dalam agama itu sendiri. Terikat dalam arti bahwa manusia perlu "mengikuti" pola historis yang tertuang dalam ajaran agama itu sendiri. Sebagai makhluk sosial, manusia berkesempatan memilih agama tertentu sebagai pilihan bebasnya atau dengan cara lain, sehingga kesinambungan konsep sosial agama dapat terus dijaga dan dilestarikan serta terus menjaga dan menciptakan perdamaian di lingkungan sosialnya.

Kedua, manusia memiliki tanggung jawab sosial terhadap sesamanya sebagai perwujudan ajaran agamanya masing-masing. Konteks ini kadang lebih mengedepankan aspek-aspek kesamaan paham atau ideologi ketimbang adanya perbedaan dengan paham atau ideologi yang dipercaya dalam agama tersebut. Tetapi, pada faktanya, justru seringkali perbedaan agama tidak menjadikan seseorang atau kelompok sosial untuk menutup diri dan bersifat curiga melainkan turut mengimplementasikan ajaran agamanya sebagai ajaran yang baik yang dapat diuji ketika mereka berbuat kepada orang lain meski berbeda iman.

Ketiga, manusia memiliki tanggung jawab untuk menyebarkan ajaran agamanya. Dalam banyak kasus, konflik internal maupun eksternal dalam setiap agama muncul atau diakibatkan oleh aspek ini. Konflik antar agama, antar suku, antar ras seringkali dipicu karena ada pihak-pihak tertentu yang mau menonjolkan ajaran agama mereka tanpa memikirkan dampak yang timbuk karenanya. Kasus Ahok tahun 2017 lalu telah menyita perhatian masyarakat Indonesia yang berimbas kepada generalisasi bahwa Kristen itu kafir dan layak masuk neraka. Gagasan-gagasan sepihak dan tidak dapat dipertanggungjawabkan telah merusak relasi antar agama dalam kelompok sosial. Dengannya, kita dapat bercermin bahwa meski manusia yang beragama memiliki kewajiban atau tanggung jawab dalam menyebarkan ajaran agamanya, tetapi ada konteks-konteks khusus yang perlu diperhatikan sehingga tidak menibulkan gejala-gejala kecurigaan atau gejala-gejala konflik antar agama dalam kelompok sosial.

Keempat, manusia bertanggung jawab terhadap pengembangan budaya yang tidak bertentangan dengan agamanya. Agama dan budaya dapat saling berdampingan untuk membentuk manusia menjadi pribadi yang mandiri, peduli, pekerja keras, dan rohani. Budaya-budaya yang ada di masyarakat perlu mendapat perhatian khusus dan melihat (menilainya) berdasarkan kacamata agama. Yang baik diteruskan, yang buruk ditinggalkan.

20 Franz Magnis Suseno, Pemikiran Karl Marx dari Sosialisme Utopis ke Perselisihan Revisioner (Jakarta: Gramedia Pustaka Utama, 2005), 72. Dikutip oleh Adon Nasrullah Jamaludin, Agama \& Konflik Sosial: Studi Kerukunan Umat Beragama, Radikalisme, dan Konflik Antarumat Beragama (Bandung: Pustaka Setia, 2015), 156. 
Kelima, manusia bertanggung jawab menjaga tatanan lingkungan (alam). Agama tidak hanya melulu berhubungan dengan Tuhan tetapi juga berhubungan dengan lingkungan. Mereka yang percaya kepada Tuhan tentu tahu bahwa alam semesta diciptakan Tuhan untuk didiami manusia. Tidak hanya mendiami alam, manusia diberikan tanggung jawab untuk menjaga, merawat, dan mengola lingkungan bagi keberlangsungan hayati mereka. Tanggung jawab manusia beragama justru kadang lebih rendah dibandingkan mereka yang tidak kurang beragama atau tidak beragama (secara resmi). Itu sebabnya, antroplogi sosial agama mengidentifikasi pokok-pokok persoalan manusia ke dalam berbagai kategori sehingga manusia dapat melihat dirinya berada pada kategori yang mana. Ketika manusia bertanggung jawab terhadap lingkungan, maka hal itu membuktikan bahwa ia sadar dan peduli terhadap hidupnya sendiri dan sesamanya.

Keenam, manusia bertanggung jawab mempertahankan ajaran agamanya. Sudah menjadi kewajiban penganut agama untuk mempertahankan agamanya masingmasing. Dalam konteks ini, keyakinan terhadap agamanya, menjadi sebuah pegangan hidup. Kehidupannya telah dibentuk oleh ajaran-ajaran agamanya, dan menjadi teladan dalam kata, pikiran, dan perbuatan. Ini telah menjadi sejarah bagi mereka yang telah berjuang mempraktikan ajaran-ajaran agamanya dan memberikan pengaruh yang baik bagi orang lain dan keberlangsungan hayati orang banyak.

Ketujuh, manusia bertanggung jawab atas dirinya sendiri berdasarkan ajaran agamanya. Manusia yang telah mempercayai ajaran-ajaran agamanya, bergerak, bertindak, berpikir, dan bertanggung jawab harus sesuai dengan ajaranajaran itu sendiri. Potensi diri dibarengi dengan keseimbangan dan pemenuhan ajaranajaran agamanya. Pribadi yang baik berangkat dari konsep agama yang baik pula. Akan tetapi, konsep "baik" menurut agama yang satu, berbeda definisi dan aktualisasinya (penerapannya) dengan agama lain. Tanggung jawab pribadi terhadap agama adalah hal umum terjadi di lingkungan masyarakat.

Ada satu lagi pembahasan soal agama yakni agama dan pemahaman medium (antara). Konteks ini berbicara tentang teks-teks Kitab Suci dalam interpretasinya yang dapat menimbulkan posisi medium: menerima dan mengubah perilaku dan menerima tanpa mengubah perilaku. Memahami tetapi melakukan yang lain bergantung pada interpretasi seseorang terhadap teks-teks kitab suci. Demikian juga dengan melakukan yang sesuai dengan teks-teks Kitab Suci. Aksentuasi signifikan di sini adalah "interpretasi harfiah", "interpretasi moderat", "interpretasi liberal", dan "interpretasi eksegetis". Dengan demikian, agama dapat bersifat mengubah ke arah yang lebih baik atau lebih buruk, mengubah relasi yang dulunya kaki menjadi harmonis, atau terus menjadi kaku dan tak berkembang.

Dari ketujuh hal yang telah disinggung di atas, yakni: 1) manusia yang bersosial terikat dengan sistem agama yang dianutnya; 2) manusia memiliki tanggung jawab sosial terhadap sesamanya sebagai perwujudan ajaran agamanya masing-masing; 3) manusia memiliki tanggung jawab untuk menyebarkan ajaran agamanya; 4) manusia bertanggung jawab terhadap pengembangan budaya yang tidak bertentangan dengan agamanya; 5) manusia bertanggung jawab menjaga tatanan lingkungan (alam); 6) manusia bertanggung jawab mempertahankan ajaran agamanya; dan 7) manusia bertanggung jawab atas dirinya sendiri berdasarkan ajaran agamanya, terkorelasi dengan potensi-potensi humanitas berikut ini: (1) potensi mempertahankan diri (ajaran agama dalam relasinya di kelompok sosial terkonteks); (2) potensi mengembangkan (ajaran agama dalam kelompok sosial); (3) potensi memecahkan [memisahkan] (memisahkan hal-hal baik dengan hal-hal buruk supaya tidak dilakukan 
secara bersamaan); (4) potensi menyatukan (menyatukan perbedaan internal maupun eksternal); (5) potensi memelihara (ajaran-ajaran agama); (6) potensi menghancurkan (menghancurkan kemunafikan, dosa, dan sebagainya); dan (7) potensi menciptakan sesuatu (menciptakan relasi yang harmonis dalam kelompok sosial majemuk).

\section{Antropologi Similaritas (Kesamaan) Hayati}

Kehidupan sosial dalam konteks mikro maupun makro terdiri atas serangkaian unsur-unsur, baik unsur kemanusiaan, agama, ras, dan sebagainya. Di samping itu, dari unsur-unsur tersebut selalu tampak adanya similaritas. Kesamaan-kesamaan yang tampak biasanya seputar moralitas, etika, tutur kata, nilai-nilai ibadah, ketaatan kepada Tuhan (Sang Pencipta), ideologi humanitas, dan lainnya. Dalam konteks similaritas tersebut, seringkali menimbulkan relasi yang baik dan harmonis. Ketika dinilai sama, maka seseorang atau kelompok tertentu merasa senang. Tetapi di sisi lain, ada pula antropologi disimilaritas (perbedaan, ketidaksamaan) yang berpotensi positif maupun negatif. Namun, ada fakta yang membuktikan bahwa meski dalam konteks antropologinya sama (similaritas) bisa memicu terjadinya konflik internal. Bahkan tak jarang menimbulkan persoalan-persoalan hukum dan HAM.

Berangkat dari antropologi similaritas di atas, potensi-potensi dalam diri manusia dapat bermunculan, atau tetap dipertahankan dan dikembangkan. Potensi-potensi tersebut adalah: (1) potensi mengembangkan (persamaan dan kesepakatan yang tercipta); (2) potensi menyatukan (persamaan yang ada disatukan menjadi sebuah komitmen bersama bagi pengembangan nilai-nilai sosial, agama, dan budaya); (3) potensi memelihara; dan (4) potensi menciptakan sesuatu (terus berinovasi bagi keberlangsungan hayati dalam konteks harmonisasi sosial dan pengembangan sumber daya manusia.

\section{Antropologi Disimilaritas (Perbedaan) Hayati}

Antropologi disimilaritas adalah bagian yang tak terpisahkan dari antropologi similaritas. Artinya, ketika ada persamaan, selalu ada perbedaan. Perbedaan adalah natur dari diri manusia dan implikasi-implikasi yang keluar dari diri manusia. Dalam kehidupan sosial mikro dan makro ada disimilaritas yang terjadi. Disimilaritas dapat muncul ke permukaan karena aspek pemikiran, komitmen, iman, agama, ideologi, suku, golongan, politik, dan sebagainya. Dalam konteks disimilaritas tersebut, seringkali menimbulkan relasi yang kurang baik baik atau bahkan konflik. Ketika dinilai berbeda, maka seseorang atau kelompok tertentu merasa tidak senang dan terganggu.

Berangkat dari antropologi disimilaritas di atas, potensi-potensi dalam diri manusia dapat bermunculan, atau tetap dipertahankan dan dikembangkan. Potensipotensi tersebut adalah: (1) potensi mempertahankan diri (meski berbeda, atau karena sikap egoisme yang kental); (2) potensi mengembangkan (perbedaan yang ada terus dijaga sebagai warisan yang tak mungkin dihindari); (3) potensi memecahkan [memisahkan] (bisa berpontensi positif maupun negatif); (4) potensi menyatukan (menyatukan perbedaan itu luar biasa tetapi bukan dengan tujuan terselubung); (5) potensi memelihara (berani berbeda tetapi tetapi menjaga keharmonisan); (6) potensi menghancurkan (bernada negatif yang disebabkan ketidaksamaan iman, konsep, pemikiran, dan sebagainya; dan (7) potensi menciptakan sesuatu (meski berbeda, inovasi berjalan terus).

\section{Antropologi Konflik}


Konflik tidak selalu muncul karena disimilaritas, tetapi juga dipicu oleh similaritas (terselubung), agama, ideologi, politik, dan kepentingan-kepentingan lainnya. Konflik yang timbul sering berimbas kepada pembunuhan, pembakaran, dan penyiksaan. Dalam konteks agama, konflik yang mengatasnamakan kitab suci tertentu, berpotensi menimbulkan perpecahan di dalam masyarakat. Kelompok-kelompok teroris telah menimbulkan keresahan dan mereka berani mempublikasikan bentuk-bentuk kejahatan mereka.

Antropologi konflik adalah bagaimana manusia melihat fakta konflik secara cermat dan tidak memiliki tendensi similaritas untuk mendukung mereka yang bersalah. Di sini, konflik dapat dilihat dari beberapa hal:

Pertama, konflik identitas di mana manusia berupaya menunjukkan identitas dan eksistensinya di depan umum (masyarakat). Identitas ini berpotensi memperlihatkan kewibawaan, komitmen, jatidiri, dan jabatan. Ketika manusia berebut identitas, maka bisa menimbulkan konflik berkepanjangan dan memicu konflik yang lebih luas.

Kedua, konflik kepentingan di mana manusia berupaya, berjuang, dan berkomitmen untuk memuluskan, meloloskan faktor-faktor kepentingannya di berbagai bidang pekerjaan atau bidang kehidupannya (di mana manusia mencari nafkah). Sering, konteks ini berimbas kepada relasi yang kurang harmonis, baik antar keluarga, antar lingkungan, antar suku, dan antar agama.

Ketiga, konflik politik di mana manusia demi partainya, rela mempergunakan berbagai cara bagi terwujudnya tujuan dan cita-cita politik partai yang dianutnya.

Keempat, konflik agama di mana manusia demi agamanya rela membela orangorang yang seagama meski mereka berbuat salah. Tak peduli benar salahnya, yang penting seagama. Kadang, konflik agama menimbulkan kehancuran moralitas dan spiritual bahkan kehancuran sosial dan bangsa. Kasus Ahok (Bazuki Tjahaya Purnama) tahun 2017 cukup mewakili konflik ini di mana Kristen menjadi sasaran empuk bagi sekelompok orang berhaluan radikal yang menuduh dengan sesuka hatinya. Itulah agama. Kadang baik, kadang buruk.

Kelima, konflik suku. Konflik ini memang pernah dan sering terjadi. Kasus di Ambon, Kalimantan, dan sebagainya cukup mewakili konflik jenis ini. Kadang, meski berbeda agama, tetapi karena satu suku, maka mereka bisa bersatu untuk melawan suku lainnya yang sedang berkonflik.

Keenam, konflik ras (rumpun bangsa) adalah konflik tercipta karena munculnya sentiment-sentimen terhadap ras tertentu, atau kebencian-kebencian yang ditujukan kepada ras tertentu. Seperti kasus beberapa waktu lalu pasca Donald Trump, presiden Amerika, mengumumkan bahwa Yerusalem adalah ibu kota negara Israel, maka bermunculan orang-orang yang membenci Amerika. Konflik ras dapat muncul karena ada orang-orang tertentu yang menebarkan paham-paham anti terhadap ras tertentu.

Dari pemaparan antropologi konflik di atas, ada potensi-potensi terkait atau yang dapat muncul dari jenis ontropologi ini, yakni: (1) potensi mempertahankan diri (meski salah, seseorang dapat saja mempertahankan dirinya benar; (2) potensi mengembangkan (meski konflik sudah reda, seseorang dapat saja menginginkan agar konflik tersebut terus berkembang menjadi konflik makro); (3) potensi memecahkan [memisahkan] (berbagai latar belakang konflik dapat ditelusuri atau dipecahkan sehingga masyarakat dapat memisahkan mana data faktual dan mana data yang direkayasa); (4) potensi menyatukan (dari konflik yang terjadi, seseorang dapat saja menyatukan dua kubu yang berkonflik); (5) potensi memelihara (perdamaian harus tetap dijaga agar tidak tercipta konflik berkepanjangan); (6) potensi menghancurkan 
(seringkali konflik bertujuan untuk menghancurkan lawan konflik, tetapi di sisi lain, potensi menghancurkan dapat bermuara pada kehancuran-kehancuran ideologi yang tidak berpihak pada nilai-nilai agama dan kemanusiaan, sehingga perdamaian dapat terus dilestarikan); dan (7) potensi menciptakan sesuatu (dalam menangani konflik, misalnya konflik berkepanjangan, maka potensi menciptakan sesuatu metode atau cara menanganinya, bisa dilakukan).

\section{Antropologi Konstruktivistik}

Manusia berada dalam lingkungan sosial mikro dan makro. Di dalamnya, manusia dapat mengembangkan berbagai potensinya. Di sini, ada potensi konstruktivistik dalam kaitannya dengan pengetahuan, baik pengetahuan normatif, agama, pendidikan khusus, pemerintahan, pertanian, ekonomi, teologi, dan sebagainya dilakukan berdasarkan perkembangan atau evolusi pengetahuan. Dalam antropologi fisik, manusia memiliki logika di mana dengan logika tersebut, manusia dapat berinteraksi dengan alam dan manusia lalu menarik kesimpulan logis sebagai interpretasinya. Namun, pengetahuan yang dimiliki selalu bersifat progresiv jika diberdayakan dan terus dikembangkan. Artinya, pengetahuan yang dimiliki manusia akan berangsung-angsur bertambah dalam pengertian bahwa interpretasi selalu membuka peluang baru, termasuk ketika ada data dan fakta yang baru.

Antropologi konstruktivistik berbicara mengenai tiga hal yaitu:

Pertama, manusia memiliki daya untuk berkembang baik dari aspek mental, fisik, karakter, cara berpikir, maupun pengetahuan. Kedua, manusia memiliki konsep untuk mengembangkan apa yang ia miliki termasuk potensi-potensi internal mencakup pengetahuan, pekerjaan, pendidikan, usaha, relasi, dan sebagainya. Ketiga, manusia memiliki hasrat untuk menjadi lebih baik agar menikmati kebahagiaan di kemudian hari. Untuk bahagia, manusia perlu mengembangkan mental, fisik, karakter, cara berpikir, pengetahuan, pekerjaan, pendidikan, usaha, relasi.

Dari ketiga hal antropologi konstruktivistik di atas, potensi-potensi berikut ini dapat menjadi muncul atau berkembang (dari yang sudah dimiliki seseorang) yaitu (1) potensi mengembangkan (pengetahuan, moral, dan sebagainya); (2) potensi memelihara (apa yang sudah ada dan dipertahankan); dan (3) potensi menciptakan sesuatu (terus berkembang dan berinovasi).

\section{Antropologi Linguistik (Komunikasi)}

Dalam dunia relasi, linguistik adalah hal yang perlu. Konteks ini membawa kita kepada pemahaman bahwa antropologi dalam arti relasi manusia dengan sesamanya, membutuhkan media penghubung yaitu "bahasa" [linguistik]. Bahasa digunakan untuk berkomunikasi. Komunikasi itu sendiri memberi dampak bagi manusia. Di sini, antropologi linguistik menekankan pada empat hal yaitu: pertama, linguistik memberi dampak bagi pengembangkan identitas manusia; kedua, linguistik memberi dampak bagi kerja sama di antara sesama manusia; ketiga, linguistik memberi dampak bagi peningkatan pekerjaan manusia, dan keempat, linguistik memberi dampak bagi potensi diri manusia dalam aspek-aspek yang dimiliki, dikuasai, dipelajari, atau disukai.

Dalam konteks historisnya, Burhan Bungin menyebutkan bahwa asal mula kajian komunikasi dalam sosiologi bermula dari akal pemikiran Karl Marx di mana Marx sendiri adalah masuk sebagai pendiri sosiologi yang beraliran Jerman, sementara Claude Hendri Saint-Simon, Auguste Comte dan Emile Durkheim merupakan namanama para ahli sosiologi yang beraliran Perancis ... Bahwa kajian dan sumbangan pemikiran Auguste Comte, Durkheim, Talcott Parson dan Robert K. Merton merupakan 
sumbangan paradigma fungsional bagi lahirnya teori-teori komunikasi yang beraliran struktural-fungsional. Sedangkan sumbangan-sumbangan pemikiran Karl Marx dan Jurgen Habermas menyumbangkan paradigma konflik bagi lahirnya teori-teori kritis dalam kajian komunikasi. ${ }^{21}$

Berkomunikasi adalah natur dari manusia. Tetap menjadi yang utama, namun sering diabaikan. Tetap menjadi penghubung, namun sering dilupakan. Tetap menjadi karakter pribadi seseorang, namun sering merusak karakter itu sendiri. Komunikasi adalah peran aktif untuk memperkenalkan pribadi seseorang kepada orang lain; merupakan kaidah dari suatu prinsip hidup seseorang. Komunikasi menghasilkan pengaruh. Signifikansi dari komunikasi adalah terletak pada tiga hal yakni: etika komunikasi, tujuan komunikasi dan isi dari komunikasi. H. M. Burhan Bungin, Guru Besar ilmu Sosiologi Komunikasi berpendapat, "pada mulanya, kajian tentang komunikasi, apalagi ilmu komunikasi adalah sesuatu yang tak pernah ada dalam khazanah ilmu pengetahuan. Ketika pada mulanya semua masalah manusia masih dalam kajian filsafat, maka komunikasi selain tidak terpikirkan atau belum dipikirkan oleh manusia (laten fenomena). ${ }^{22}$ Menurutnya, khazanah keilmuan komunikasi dipengaruhi oleh ilmu-ilmu sosial di mana ilmu sosial adalah induk dari ilmu komunikasi, di samping itu juga ilmu komunikasi dipengaruhi oleh ilmuwannya dan "stakeholder" akademik di sekitarnya. ${ }^{23}$

H. A. W. Widjaja ${ }^{24}$ menunjukkan berbagai definisi tentang komunikasi dari para ahli, antara lain: James A. F. Stoner, dalam bukunya, Manajemen, menyebutkan bahwa komunikasi adalah proses di mana seseorang berusaha memberikan pengertian dengan cara pemindahan pesan. John R. Schemerhorn cs. dalam bukunya yang berjudul, Managing Organizational Behavior, menyatakan bahwa komunikasi itu dapat diartikan sebagai proses antar pribadi dalam mengirim dan menerima simbol-simbol yang berarti bagi kepentingan mereka. William F. Glueck, dalam bukunya yang berjudul, Manajemen, menyatakan bahwa komunikasi dapat dibagi dalam dua bagian utama, yaitu: a) Intepersonal Communication, komunikasi antar pribadi yaitu proses pertukaran informasi serta pemindahan pengertian antara 2 orang atau lebih di dalam suatu kelompok kecil manusia; b) Organizational Communications, yaitu di mana pembicara secara sistematis memberikan informasi dan memindahkan pengertian kepada orang banyak di dalam organisasi dan kepada pribadi-pribadi dan lembagalembaga di luar yang ada hubungan.

Dari uraian singakat di atas maka potensi-potensi berikut ini dapat terwujud atau dikembangkan, atau muncul ketika peristiwa komunikasi dalam konteks relasi (untuk tujuannya masing-masing): (1) potensi mempertahankan diri (biasanya aspek-aspek prinsipil dapat dipertahankan dalam bentuk bagaimana mengkomunikasikannya); (2) potensi mengembangkan (bagaimana berkomnunikasi yang baik); (3) potensi memecahkan [memisahkan] (berbagai persoalan dapat ditempuh dengan berkomunikasi yang baik [penggunaan diksi atau linguistik yang baik dan sopan]) (4) potensi menyatukan (dengan komunikasi yang baik, ada hal-hal tertentu yang dapat disatukan); (5) potensi memelihara (bahasa yang baik dapat memelihara situasi dan kondisi tertentu); (6) potensi menghancurkan (hubungan akan terak atau terganggu

21 H. M. Burhan Bungin, Sosiologi Komunikasi: Teori, Paradigma dan Diskursus Teknologi Komunikasi di Masyarakat, (Jakarta: Kencana, 2011), 19.

22 Bungin, Sosiologi Komunikasi, 3.

${ }^{23}$ Bungin, Sosiologi Komunikasi, 240.

${ }^{24}$ H. A. W. Widjaja, Komunikasi: Komunikasi dan Hubungan Masyarakat, (Jakarta: PT Bumi Aksara, 2002) 
atau bahkan hancur [terpisah] ketika komunikasi seseorang tidak baik); dan (7) potensi menciptakan sesuatu (komunikasi dapat terus dikembangkan sampai kepada inovasi).

\section{Antropologi Normatif (Moral)}

Di kelompok sosial, aspek normatif adalah hal yang umum. Meski dalam satu lingkungan sosial terdiri atas berbagai agama dan suku, aspek norma atau aturan yang umum yang berlaku selalu ada. Artinya, pandangan manusia tentang sesuatu yang baik dan buruk selalu memiliki similaritas. Ini yang disebut dengan normatif. Antropologi normatif berbicara mengenai tiga hal:

Pertama, manusia perlu menerapkan unsur-unsur normatif yang berlaku secara umum. Kedua, manusia perlu mempertahankan unsur-unsur normatif yang berlaku secara umum. Ketiga, manusia perlu menularkan unsur-unsur normatif yang berlaku secara umum. Unsur-unsur normatif yang berlaku secara umum antara lain: 1) berbuat baik kepada orangtua; 2) berbuat baik kepada sesama meski berbeda agama; 3) saling tolong menolong dalam memberi bantuan; 4) saling menghargai satu dengan lainnya; 5) bergotong royong dalam membangun lingkungan; 6) saling menghormati; 7) menjaga perdamaian dan keamanan di lingkungan mikro maupun makro.

Dari antropologi normatif ini, potensi-potensi berikut ini dapat dijadikan sebagai pegangan atau dapat dikembangkan ketika baru memulainya: (1) potensi mempertahankan diri (yang dipertahankan adalah kebaikan-kebaikan yang telah melekat dalam diri dan telah terpublikasi dalam proses kehidupan); (2) potensi mengembangkan (terus berupaya mengembangkan hal-hal baik [normatif]); (3) potensi menyatukan (dengan aspek-aspek normatif, kita bisa menyatukan persepsi untuk terus berbuat baik baik dalam tataran keluarga, lingkungan, maupun masyarakat luas; dan (4) potensi memelihara (terus memelihara aspek-aspek normatif).

\section{Antropologi Logikalisme (Berpikir)}

Di sini, saya memberi pemamahan tambahan dari interaksionisme simbolik. Logikalisme secara sederhana adalah sebuah paham di mana manusia memiliki sejumlah konsep diri berdasarkan pemikirannya, pengamatannya, analisisnya, dan interpretasi atas konsep tersebut. Logikalisme menggiring manusia untuk melihat dirinya sebagai objek kajian sekaligus subjek penelitian. Apa yang dilihat manusia terhadap dirinya dan orang lain adalah bagian dari pembelajaran antropologi fisik di mana manusia berpotensi menciptakan berbagai gagasan-gagasan rasional bahkan spektakuler yang dihasilkan dari kekuatan pikiran (logika). Dunia antropologi juga sangat menekankan usur dan pengaruh logikalisme.

Hal ini terkait erat dengan teori interaksionisme simbolik. Salah satu tokohnya adalah George Herbert Mead (pemikir yang paling penting di dalam sejarah interaksionisme simbolik). Bukunya berjudul Mind, Self and Society adalah karya tunggal yang paling penting dalam tradisi itu. ${ }^{25}$ George Ritzer menjelaskan bahwa beberapa interaksionis simbolik seperti Herbert Blumer, Jerome Manis dan Bernard Meltzer, Arnold Rose, David A. Snow, yang telah mencoba menyebutkan satu demi satu prinsipprinsip dasar teori itu. Prinsip-prinsip itu mencakup hal-hal berikut ini:

1. Manusia, tidak seperti hewan-hewan yang lebih rendah, diberkahi dengan kemampuan untuk berpikir.

25 George Ritzer, Teori Sosiologi: Dari Sosiologi Klasik Sampai Perkembangan Terakhir Postmodern, alih bahasa Saut Pasaribu, Rh. Widada, Eka Adi Nugraha (Yogyakarta: Pustaka Pelajar, 2014), 602. 
2. Kemampuan untuk berpikir dibentuk oleh interaksi sosial

3. Dalam interaksi sosial orang mempelajari makna dan simbol-simbol yang memungkinkan, mereka melaksanakan kemampuan manusia yang khas untuk berpikir.

4. Makna-makna dan simbol-simbol memungkinkan orang melaksanakan tindakan dan interaksi manusia yang khas.

5. Orang mampu memodifikasi atau mengubah makna-makna dan simbol-simbol yang mereka gunakan di dalam tindakan dan interaksi berdasarkan penafsiran mereka atas situasi.

6. Orang mampu membuat modifikasi-modifikasi dan perubahan-perubahan itu, sebagian karena kemampuan mereka berinteraksi dengan dirinya sendiri, yang memungkinkan mereka memeriksa rangkaian tindakan yang mungkin, menaksir keuntungan-keuntungan dan kerugian-kerugian relatifnya, dan kemudian memilih salah satu di antaranya.

7. Pola-pola tindakan dan interaksi yang terangkai membentuk kelompokkelompok dan masyarakat-masyarakat. ${ }^{26}$

Bagi Ritzer, kemampuan untuk berpikir memampukan orang bertindak secara reflektif dari pada hanya berperilaku secara tidak efektif. Orang harus sering menyusun dan memandu apa yang mereka lakukan, dari pada sekadar melepaskannya begitu saja. ${ }^{27}$ Selain itu, kemampuan untuk berpikir tertanam di dalam pikiran, tetapi para interaksionis simbolik mempunyai suatu konsepsi yang kurang lazim mengenai pikiran sebagai hal yang berasal dalam sosialisasi kesadaran. ${ }^{28}$ Ritzer berpendapat, pikiran adalah suatu proses yang dirinya sendiri merupakan bagian dari proses stimulus dan respons yang lebih besar. Pikiran dihubungkan ke hampir segala aspek interaksionisme simbolik lainnya, termasuk sosialisasi, makna-makna, simbol-simbol, diri, interaksi, dan bahkan masyarakat. ${ }^{29}$ Dari pengamatannya, Ritzer menyimpulkan bahwa "Orang hanya memiliki kemampuan umum untuk berpikir. Kemampuan itu harus dibentuk dan diperbaiki di dalam proses interaksi sosial. Kemampuan manusia untuk berpikir dikembangkan sejak dini dalam sosialisasi masa kanak-kanak dan diperbaiki selama sosialisasi masa dewasa." 30

Konteks berpikir adalah konteks umum. Manusia yang hidup adalah manusia yang berpikir. Tujuan berpikir adalah pertama, mencari jalan bagaimana untuk mendapatkan sesuatu; kedua, memikirkan bagaimana memakai atau menggunakan segala sesuatu yang ada pada dirinya; ketiga, berpikir tentang bagaimana bertahan hidup; keempat, berpikir bagaimana menyenangkan orang lain; kelima, berpikir bagaimana bekerja untuk mendapatkan lebih dari apa yang dimiliki; keenam, berpikir bagaimana keluar dari masalah atau problem; dan ketujuh, berpikir bagaimana menyelesaikan berbagai pekerjaan yang dikerjakan.

\section{Antropologi Biblika}

Antropologi berdasarkan perspektif biblika memiliki persamaan dengan antropologi umum, namun perbedaannya adalah konsep biblika menembus sampai kepada substansi pencipraan, dosa, moral, eskatologis, dan masih banyak lagi. Henry C.

${ }^{26}$ Ritzer, Teori Sosiologi, 625.

27 Ritzer, Teori Sosiologi, 627.

${ }^{28}$ Ritzer, Teori Sosiologi, 627.

${ }^{29}$ Ritzer, Teori Sosiologi, 627.

30 Ritzer, Teori Sosiologi, 627. Konteks ini dapat disebut dengan pengetahuan (kemampuan berpikir dan menganalisis) konstrukstivistik atau kontruksitivisme. 
Thiessen menyebutkan, antropologi teologis membahas manusia dalam hubungannya dengan Allah, sedangkan antropologi ilmiah menguraikan organisme psikofisik serta sejarah alamiah manusia. ${ }^{31}$ Menurut Berkhof, antropologi Teologis hanyalah berkaitan dengan apa yang dikatakan Alkitab tentang manusia dan hubungan di mana manusia harus berdiri di hadapan Allah. Antropologi Teologis hanya melihat Alkitab sebagai satu-satunya sumber, dan membaca ajaran tentang pengalaman manusia dalam terang Firman Tuhan. ${ }^{32}$

Anthony A. Hoekema berpendapat, "kita bisa membedakan tipe-tipe antropologi non-Kristen. Menurut antropologi idealistik, manusia pada dasarnya adalah roh dan tubuh fisiknya merupakan hal yang asing bagi natur sejatinya. Menurut Plato, apa yang nyata dari manusia adalah intelektual atau rasionya, yang dianggap merupakan percikan ilahi di dalam diri seseorang yang akan terus bereksistensi bahkan setelah tubuhnya mati. Akan tetapi, tubuh manusia terdiri dari materi yang merupakan realitas yang lebih rendah; tubuh ini merupakan penghambat bagi roh, dan seseorang akan benar-benar lebih baik jika tidak memiliki tubuh."33 Yang kedua adalah antropologi materialistik yang menjelaskan bahwa manusia terdiri dari unsur-unsur materi, sedangkan kehidupan mental, emosional, dan rohnya hanya merupakan produk sampingan dari struktur materialnya. ${ }^{34}$

Paul Enns menilai lain. Menurutnya, ada beragam pandangan dari orang Kristen dan non-Kristen tentang asal mula manusia. Orang non-Kristen pada umumnya berpegang pada evolusi ateistik atau humanistik. ${ }^{35}$ Evolusi ateistik (evolusionari) dimulai oleh Charles Darwin dan yang ditajamkan oleh yang lain adalah suatu usaha untuk menjelaskan asal mula manusia dan kehidupan terlepas dari Allah. ${ }^{36}$ Sebenarnya, gagasan atau teori Darwin tidak menarik untuk dibahas karena penemuannya belakangan dan tidak disertai dokumen tertulis sebelumnya, sedangkan gagasan atau teori tentang manusia dan seluk beluknya telah begitu jelas digambarkan dan diungkapkan kepada kita secara sistematis. Enns mengemukakan, "Evolusi teistik adalah pengajaran bahwa tumbuh-tumbuhan, binatang dan manusia secara bertahap berevolusi dari bentuk yang lebih rendah, dan proses disupervisi oleh Allah. ${ }^{37}$ Menurut Enns, ada beberapa masalah yang serius yang dihadapi oleh evolusionis teistik. Apabila umat manusia adalah hasil evolusi maka Adam bukan merupakan pribadi historis dan analogi antara Kristus dan Adam dalam Roma 5:12-21 tidak dapat diterima."38

Dalam pemikiran Charles C. Ryrie tentang konteks asal mula manusia, evolusi mengajarkan bahwa ia berputar dalam jangka waktu lama melalui aksi perubahan dan seleksi alamiah dari yang sederhana, beralih menjadi bentuk lain yang pada mulanya berasal dari makhluk bersel tunggal. Nyatalah bahwa dasar dari evolusi naturalistis

31 Henry C. Thiessen, Teologi Sistematika, direvisi oleh Vernon D. Doerksen, (Malang: Gandum Mas, 2015), 229. 2013), 4 .

${ }^{32}$ Louis Berkhof, Teologi Sistematika: Doktrin Manusia, terj. Yudha Thianto (Surabaya: Momentum,

33 Anthony A. Hoekema, Manusia: Ciptaan menurut Gambar Allah, terj. Irwan Tjulianto (Surabaya: Momentum, 2003), 3. Judul asli Created in God's Image, (Grand Rapids, Michigan: Wm. B. Eerdmans Publishing Company).

34 Hoekema, Manusia, 3.

35 Paul Enns, The Moody Handbook of Theology, alih bahasa Rahmiati Tanudjaja (Malang: Literatur SAAT, 2003), 371.

${ }^{36}$ Enns, The Moody Handbook of Theology, 371-72.

37 Enns, The Moody Handbook of Theology, 372.

38 Enns, The Moody Handbook of Theology, 372. 
adalah sains dan kepercayaan ("iman"). ${ }^{39}$ Ryrie menjelaskan mengenai prinsip-prinsip evolusi:

Evolusi bersandar pada beberapa prinsip dasar: (1) planet-planet dan bintangbintang adalah berasal dari ledakan dahsyat proton dan netron yang dimampatkan ${ }^{40}$ dan berputar. Hasil ledakan tersebut yang merupakan benda padat yang dimampatkan itu, terus berkembang menjauh dari inti semula pada kecepatan yang fantastis. Pilihan lain dari prinsip ini, yang disebut juga teori "keadaan tetap", yang mempercayai bahwa benda-benda terus-menerus terbentuk di angkasa luar dan proses ini berlangsung dalam masa yang tak terbatas. (2) kehidupan dimulai semata-mata melalui kesempatan tatkala satu sel tunggal muncul dari materi yang tak hidup. (3) sesudah dimulai melalui kesempatan, semua organism kehidupan lalu berkembang dari yang pertama tadi dan bentuk-bentuk sederhana selanjutnya bertahap bertambah kerumitannya. Perkembangan ini kemudian menghasilkan manusia. ${ }^{41}$

Bertolak belakang dengan gagasan evolusi, Ryrie berpendapat, "Karya penciptaan manusia didasarkan atas perundingan sidang Allah. Walau semua ciptaan-Nya sampai sebelum jadinya manusia dikatakan baik, namun ciptaan tersebut belum lengkap bila tanpa manusia. Manusia bukan dipikirkan-Nya kemudian, melainkan hasil pemikiran terdahulu dalam benak Allah. Setelah Allah menciptakan manusia barulah Ia kemudian berkata bahwa apa yang Ia kerjakan adalah 'amat baik'" (Kej. 1:31). ${ }^{42}$ Penciptaan manusia tidak melibatkan proses evolusi apa pun yang menghubungkan manusia dengan makhluk pra manusia yang berbentuk lebih sederhana. ${ }^{43}$

Menyikapi dualisme perspektif antropologi antara Kristen dan non-Kristen, Thiessen menyatakan, "jelas, ada perbedaan di antara keduanya. Alasannya adalah berbeda untuk pokok-pokok bahasan, dan bukan cara-cara pembahasan. Hal ini perlu dikatakan karena antropologi ilmiah tidaklah lebih ilmiah dari pada antropologi teologis, tetapi hanya membahas aspek-aspek yang berbeda dari ajaran tentang manusia."44 Hoekema menegaskan, "salah satu presaposisi dasar dari pandangan Kristen tentang manusia adalah kepercayaan kepada Allah sebagai Pencipta. Pribadi manusia tidak bereksistensi secara otonom atau independen, melainkan sebagai ciptaan Allah (Kej. 1:27). Implikasi yang jelas dari fakta penciptaan adalah bahwa semua realitas ciptaan seutuhnya tergantung kepada Allah." 45 Ia menambahkan, "Alkitab dengan sangat jelas menyatakan bahwa segala benda dan semua makhluk yang diciptakan, sepenuhnya tergantung kepada Allah. "Hanya Engkau adalah TUHAN! Engkau telah menjadikan langit, ya langit segala langit dengan segala bala tentaranya, dan bumi dengan segala yang ada di atasnya, dan laut dengan segala yang ada di dalamnya. Engkau memberi hidup kepada semuanya itu dan bala tentara langit sujud menyembah kepada-Mu" (Neh. 9:6)."46 Kutipan Kisah Para Rasul 17:25, 28 meneguhkannya, “... karena Dialah yang memberikan hidup dan nafas dan segala

39 Charles C. Ryrie, Teologi Dasar I: Panduan Populer untuk Memahami Kebenaran Alkitab (Yogyakarta: ANDI, 2014), 250.

40 Dipadatkan atau dihentikan.

41 Ryrie, Teologi Dasar I, 253.

42 Ryrie, Teologi Dasar I, 276.

43 Ryrie, Teologi Dasar I, 276-77.

44 Thiessen, Teologi Sistematika, 229.

45 Hoekema, Manusia, 7.

46 Hoekema, Manusia, 7. 
sesuatu kepada semua orang. Sebab di dalam Dia kita hidup, kita bergerak, kita ada, seperti yang telah juga dikatakan oleh pujangga-pujanggamu: Sebab kita ini dari keturunan Allah juga" (Kis. 17:25, 28). Berangkat dari gagasan ini, Hoekema menilai bahwa "manusia bukan sekadar sebuah ciptaan; ia juga adalah satu pribadi. Menjadi satu pribadi berarti memiliki suatu bentuk kemandirian - bukan mutlak tetapi relatif. Menjadi satu pribadi berarti mampu membuat keputusan, menetapkan tujuan, dan bergerak ke arah tujuan-tujuan itu. Ini berarti [manusia] memiliki kebebasan setidaknya dalam arti ia mampu membuat pilihan-pilihannya sendiri." 47

Ada berbagai pandangan yang menggagas kisah historis manusia. Theissen mencatat bahwa, "golongan evolusionis yang berhaluan teistis mengajarkan bahwa manusia itu merupakan hasil proses evolusi alamiah dari suatu bentuk kehidupan yang lebih sederhana. Golongan evolusi ambang dan golongan kreasionisme beranggapan bahwa manusia diciptakan langsung oleh Allah. ${ }^{48}$

\section{a. Asal usul jiwa}

Teori pra-eksistensi. Menurut teori ini, jiwa sudah ada dalam keadaan tertentu sebelum terbentuk tubuh dan baru memasuki tubuh pada suatu saat tertentu pada awal perkembangan tubuh. Plato, Philo, dan Origenes menganut pandangan ini. ${ }^{49}$ Plato mengajarkan teori ini untuk menerangkan mengapa manusia bisa mempunyai gagasangagasan di dalam dirinya yang tidak diperolehnya melalui masukan-masukan dari pancainderanya. ${ }^{50}$ Philo mengajarkannya untuk menerangkan bagaimana jiwa terpenjara di dalam tubuh, dan Origenes menerima teori ini untuk menerangkan bagaimana manusia bisa lahir dalam kondisi yang berbeda-beda. Beberapa pihak telah menganut pandangan ini untuk menerangkan kebejatan yang diwarisi. ${ }^{51}$ Menurut Thiessen, teori ini bertolak belakang dengan ajaran Kitab Suci misalnya dalam Roma 5:14-19. Ryrie menambahkan, "pandangan ini mengatakan bahwa pada mulanya Allah menciptakan semua jiwa yang terkurung dalam tubuh jasmaniah sebagai hukuman. Jiwa-jiwa tersebut lalu melewati berbagai inkarnasi sepanjang sejarah dan dalam proses membuang dosa. Plato dan orang Yunani mengajarkan paham perpindahan jiwa-jiwa ini. Pada masa permulaan gereja, bapa gereja Origenes berpegang pada paham ini (185-254). Pada masa kini paham ini diajarkan oleh agama Hindu."52

Teori penciptaan. Menurut teori ini, jiwa tiap-tiap orang langsung diciptakan oleh Allah. Jiwa itu memasuki tubuh pada tahap awal perkembangan tubuh, mungkin pada saat penghamilan. Hanya tubuh yang merupakan hasil pengembangbiakan dari generasi sebelumnya. Teori ini memelihara sifat rohani jiwa. Beberapa teks dukungan untuk teori ini adalah Bilangan 16:22, Pengkhotbah 12:7; Yesaya 57:16, Zakharia 12:1, Ibrani 12:9. Aristoteles, Ambrosius, Yerome, dan Pelagius dan bertahun-tahun kemudian juga Anselmus, Aquinas serta sebagian besar teolog Katolik Roma dan Reformasi mendukung teori ini. ${ }^{53}$ Ryrie menjelaskan, pandangan ini dipertahankan oleh Charles Hodge ${ }^{54}$ (Systematic Theology. Ia berpendapat bahwa Allah menciptakan jiwa pada saat konsepsi (pembuahan) atau kelahiran, dan segera terpadu dengan tubuh. Jiwa itu berdosa bukan karena cacat melainkan karena kontak dosa warisan

\footnotetext{
47 Hoekema, Manusia, 8.

48 Thiessen, Teologi Sistematika, 231.

49 Thiessen, Teologi Sistematika, 250.

50 Thiessen, Teologi Sistematika, 250-51.

51 Thiessen, Teologi Sistematika, 251.

52 Ryrie, Teologi Dasar I, 282.

53 Thiessen, Teologi Sistematika, 251.

54 Systematic Theology (Grand Rapids: Eerdmans, 1940), 2:70
} 
melalui tubuh. ${ }^{55}$ Hodge mengemukakan tiga alasan untuk mempertahankan pandangannya:

(1) pandangan ini lebih sesuai dengan Alkitab seperti Bilangan 16:22 dan Ibrani 12:9 yang mengatakan bahwa jiwa datang dari Allah (dikontraskan dengan tubuh yang berasal dari orangtua di bumi. (2) karena jiwa itu sifatnya kekal maka jiwa tak dapat diteruskan lewat keturunan. (3) ketidakberdosaan Kristus hanya bisa terjadi jika jiwa-Nya diciptakan (dan tentunya jiwa tersebut tidak disatukan dengan tubuh yang berdosa - jadi manusia-Nya tidak berdosa). Para teolog Katolik dan banyak teolog Reformasi menganut pandangan penciptaan ini. ${ }^{56}$

Tanggapan Thiessen adalah bahwa teori ini tidak dapat menerangkan kecenderungan dalam diri manusia untuk berbuat dosa. Menurut pandangan ini salah satu dari kedua hal inilah yang terjadi, yaitu Allah telah menciptakan setiap jiwa dalam keadaan yang penuh dengan dosa, atau jiwa langsung tercemar ketika bersentuhan dengan tubuh. Bila hal pertama yang benar maka itu berarti Allah secara langsung adalah Pencipta dosa; sedangkan bila hal kedua benar maka Allah secara tidak langsung menjadi penyebab dosa. ${ }^{57}$ Menurut saya, Thiessen tidak menyentuh wilayah pemikiran lainnya yakni: pertama, terlalu naif ketika menyatakan bahwa Tuhan menciptakan setiap jiwa dalam keadaan yang penuh dosa. "Penuh dosa" seperti apa yang dimaksudkan? Dosa yang dipahami di sini-dugaan saya-hanyalah dikategorikan sebagai "dosa yang ada pada manusia pada umumnya". Sedangkan jiwa yang diciptakan Tuhan di dalam tubuh pada awal kejadiannya, tidaklah diklaim penuh dosa. Dosa belum dipahami oleh bayi apalagi dengan mengatakan "jiwanya penuh dengan dosa". Dosa dilakukan secara fisik (pikiran, perkataan, perbuatan). Ini terlalu berlebihan dan menghakimi; kedua, Tuhan sebagai pencipta jiwa manusia yang murni tanpa tercemar ketika masuk dan menyatu dengan tubuh. Soal tercemar dosa bukanlah menjadi fokus utama sebab secara natur memang tubuh tercemar oleh dosa tetapi secara faktual, personalitas manusia belum mampu memahami antara yang baik dan jahat seperti terjadi pada seorang bayi.

Teori tradusian. Seluruh umat manusia telah diciptakan di dalam Adam, baik tubuh maupun jiwanya, dan bahwa keduanya itu diturunkan dari dia kepada semua keturunannya. Tertulianus tampaknya yang mengusulkan pandangan ini. Para teolog aliran Lutheran pada umumnya menerima pandangan ini. ${ }^{58}$ Teori tradusian hampir sama dengan teori pra eksistensi. Sebab jika seluruh manusia, baik tubuh dan jiwanya diturunkan dari Adam dan Hawa, bukankah dengan begitu menegaskan bahwa jiwa sudah ada dalam keadaan tertentu sebelum terbentuk tubuh?

Ryrie menambahkan, "pandangan ini mengatakan bahwa jiwa ditularkan bersama badan melalui proses keturunan. William G. T. Shedd, Dogmatic Thoelogy (New York: Scribners, 1891), 2:7, memberi tiga alasan untuk mendukung paham ini: (1) Ibrani 7:10 menunjukkan adanya perbuatan rasional dan moral dari sebagian orang Lewi yang belum lahir; Kejadian 2:1-3 menyatakan bahwa Allah beristirahat pada hari ketujuh dari Penciptaan karena pekerjaan-Nya telah selesai. Tak ada karya baru seperti menciptakan jiwa baru dan ayat 7 tidak memungkinkan napas hidup ditiup kepada orang lain selain Adam. (2) secara teologis Penciptaan menempatkan Allah pada posisi

\footnotetext{
55 Ryrie, Teologi Dasar I, 282.

${ }^{56}$ Ryrie, Teologi Dasar I, 283.

57 Thiessen, Teologi Sistematika, 252-53.

58 Thiessen, Teologi Sistematika, 253.
} 
menciptakan jiwa yang sempurna (Ia tidak dapat menciptakan seorang yang berdosa), lalu masing-masing mengalami kejatuhan pada saat dilahirkan. Hanya Kristus saja yang merupakan kekecualian dari masalah ini. (3) secara jasmaniah manusia selalu dipandang sebagai kesatuan dari tubuh dan jiwa; karena itu dipertimbangkan bersama sebab berkembang bersama." 59 Ryrie berkesimpulan, kelihatannya pandangan ini lebih memberikan penjelasan yang lebih wajar dari pada pandangan Penciptaan. ${ }^{60}$

Teori baru. Saya mengusulkan teori lainnya yaitu teori genetika. Teori ini adalah akumulasi dari dua teori sebelumnya yakni praeksistensi dan tradusian. Menurut saya, di dalam diri setiap manusia, Tuhan telah memberikan potensi kepada manusia terciptanya "jiwa dan tubuh baru" melalui hubungan biologis. Manusia adalah makhluk hidup yang berpotensi menghasilkan makhluk hidup yang sama. Hal ini didasarkan pada proses peniupan "roh" pertama kali oleh Tuhan kepada Adam (Kej. 2:7). Setelah itu, tidak ada lagi peniupan "roh" untuk penciptaan manusia-manusia berikutnya. Potensi menciptakan jiwa baru terwujud dalam hubungan biologis antara laki-laki dan perempuan. Sederhananya, manusia tercipta [lahir] sebagai implikasi penyatuan dua kromoson yang lahir, keluar dari dalam tubuh manusia itu sendiri (laki-laki dan perempuan). Artinya, "jiwa dan tubuh baru" sudah ada sejak awal penciptaan Adam dan Hawa dan terealisasi kemudian telah manusia melakukan hubungan biologis. Mengapa disebut "potensi"? Sebabnya adalah "ada juga manusia yang tidak dapat menurunkan "jiwa dan tubuh yang baru" melalui hubungan biologis alias mandul.

Tuhan tidak menciptakan anak-anak Adam (seperti Ia menciptakan Adam dan Hawa), melainkan melalui Adam dan Hawa dengan potensi genetik yang diberikan-Nya dalam tubuh mereka, maka mereka berpotensi untuk menghasilkan keturunan. Jadi, implikasi logis dari faktor genetik dalam tubuh manusia, sangat berpotensi untuk melahirkan anak-anak manusia selanjutnya. Lalu bagaimana dengan peristiwa kelahiran Yesus? Peristiwa kelahiran Yesus tetap menggunakan potensi terciptanya "jiwa dan tubuh baru", hanya saja eksistensi Jiwa dan Tubuh Yesus tidak dilakukan dengan penyatuan biologis sebagaimana manusia pada umumnya melainkan adanya campur tangan Ilahi (Roh Kudus) dengan menggunakan rahim Maria dan kromosomnya (potensi pembentukan tubuh baru secara alamiah), yang berimplikasi logis - supranatural mengenai kelahiran Yesus. Logis artinya Yesus lahir secara normal layaknya manusia dan proses pembentukan-Nya secara jasmani mengikuti proses pada umumnya. Supranatural artinya Yesus ada dan terbentuk dalam rahim Maria (tubuh) melalui campur tangan Ilahi yang tidak ada duanya di dunia ini. Kuasa Dia yang Mahatinggi menaungi rahim Maria dan terjadinya secara biologis. Artinya, Tuhan menggantikan posisi kromoson x (dari laki-laki) dengan kuasa yang luar biasa ajaibnya.

\section{b. Manusia dan dosa}

Dosa, atau dalam pandangan umum dianggap sebagai "salah", "melanggar", "pelanggaran", kurang baik", dan sebutan lain, adalah definisi yang dipikirkan manusia berdasarkan tiga hal: pertama, berdasarkan pada pandangan kebiasaan; kedua, berdasarkan kitab suci; dan ketiga, berdasarkan definisi personal (subjektif). Pada pandangan kebiasaan, definisi yang dimunculkan adalah definisi karena pandangan mayoritas yang dianggap sepaham, sesuai, dan faktual. Pada pandangan kitab suci, definisi yang dimunculkan adalah berdasarkan dokumen dan empirical di mana Tuhan menyebutnya dengan berbagai macam sesuai konteksnya. Pada definisi personal,

${ }^{59}$ Ryrie, Teologi Dasar I, 283.

60 Ryrie, Teologi Dasar I, 283. 
adalah definisi yang dipandang sebagai bentuk pemikiran internal dan menafsirkannya melalui perasaan pribadi tanpa ada peluang bagi yang lain untuk ikut mendefinisikannya.

Louis Berkhof mengartikan dosa sebagai "tidak menyesuaikan diri dengan hukum moral Allah, baik dalam perbuatan, dalam watak, ataupun dalam keadaan. (Systematic Theology, 233). ${ }^{61}$ Buswell ${ }^{62}$ mengartikannya sebagai "segala sesuatu di dalam diri makhluk ciptaan yang tidak mengungkapkan, atau yang bertolak belakang dengan, sifat kudus Sang Pencipta. ${ }^{63}$ Dosa dilakukan dengan beberapa cara: perbuatan (fisik, moral), perkataan, pikiran, spiritual. Kejatuhan manusia dalam dosa, atau dengan kata lain "terciptanya [adanya] dosa dalam dunia sekarang ini berawal dari "adu argumentasi yang melibatkan pikiran, perkataan, dan perbuatan di Taman Eden. Manusia diciptakan dengan berbekal potensi internal yang aktif. Potensi manusia diciptakan untuk menghasilkan dualism keputusan: baik dan jahat. Di sini, perlu hati-hati untuk memikirkan bahwa dari mana dosa berasal. Tuhan tidak menciptakan dosa, tetapi Ia menciptakan potensi.

Antropologi biblika memiliki sasaran yang terdiri atas: 1) Manusia memahami identitas naturiahnya; 2) Manusia memahami signifikansinya dengan sesama; 3) Manusia memahami tugas dan tanggung jawabnya yang diberikan Tuhan; 4) Manusia memahami bahwa tubuh jasmani ini patut dijaga; 5) Manusia memahami bahwa kerusakan tubuh diakibatkan oleh ulah manusia itu sendiri (manusia berdosa dan terus menyiksa dirinya dengan berbagai-bagai duka [dosa]).

\section{c. Gambar dan Rupa}

Mengenai frasa "menurut gambar dan rupa Kita", Hoekema menjelaskan bahwa kata gambar, "tselem", dan rupa, "demuth", di dalam bahasa Ibrani tidak ada kata sambung di antara kedua ungkapan tersebut. Baik Septuaginta maupun Vulgata memasukkan kata "dan", dan sehingga memberi kesan bahwa "gambar" dan "rupa" mengacu kepada dua hal yang berbeda. ${ }^{64}$ Kedua kata tersebut memiliki sedikit perbedaan. Hoekema menjelaskan, kata "tselem" diturunkan dari akar kata yang bermakna "mengukir" atau "memotong". 65 Dalam Kejadian 1, kata "tselem" mengindikasikan bahwa manusia menggambarkan Allah, artinya manusia merupakan suatu representasi Allah. Kata "demuth" bermakna menyerupai.66 Kata "demuth" mengindikasikan bahwa gambar tersebut juga merupakan keserupaan, "gambar yang menyerupai Kita. Kedua kata tersebut member tahu bahwa manusia merepresentasikan Allah dan menyerupai Dia dalam hal-hal tertentu. ${ }^{67}$

Ryrie menambahkan, kata "gambar", Ibrani, tselem, berarti gambar yang dihias, suatu bentuk dan figur yang representatif. Satu gambar dalam pengertian yang nyata (2 Raj. 11:18; Yeh. 23:14; Am. 5;26), dan kata "rupa", demuth, (Lat., imago dan similitude, dalam PB digunakan kata eikon dan homoiosis, mengacu pada arti kesamaan tapi lebih bersifat abstrak atau ideal. Dengan memakai dua kata itu secara bersamaan, penulis "sepertinya berupaya untuk menyatakan ide yang amat sulit yanag menjelaskan bahwa

61 Thiessen, Teologi Sistematika, 263.

${ }^{62}$ A Systematic Theology of the Christian Religion, 264.

63 Thiessen, Teologi Sistematika, 263.

64 Hoekema, Manusia, 17-18.

65 Francis Brown, S. R. Driver, dan Charles Briggs, Hebrew and English Lexicon of the Old Testament (New York: Houghton Mifflin, 1907), 853, dikutip Hoekema, Manusia, 18.

${ }^{66}$ Brown, Driver, dan Briggs, Hebrew and English Lexicon of the Old Testament, 197-98. Dikutip Hoekema, Manusia, 18.

67 Hoekema, Manusia, 18. 
manusia dalam hal tertentu merupakan refleksi yang nyata dari Allah namun sekaligus juga penulis mengartikannya secara rohani yang bersifat abstrak. ${ }^{68}$ Menurut Hermann Bavink, kata 'gambar' dan 'rupa' - Ibrani tselem dan děmût, eikōn dan homoiosis) sudah pasti tidak identik. Tidak ada distingsi material yang esensial yang harus dibuat di antara keduanya. Keduanya digunakan secara saling menggantikan, dan penggantian tersebut tidak memiliki alasan yang spesifik (Kej. 1:26; 5:3) tetapi dalam Kejadian 1:27 dan 9:6 (bdk. Kol. 3:10) hanya 'gambar' yang dirujuk, dan di dalam Kejadian 5:1 dan Yakobus 3:9 hanya 'rupa'.69

Terkait dengan konteks ini, Herman Bavink menyatakan: menurut Alkitab, manusia tidak hanya menyandang gambar Allah, tetapi manusia adalah gambar Allah, dan bahwa gambar Allah mencakup manusia di dalam keseluruhan dirinya. ${ }^{70}$ Hoekema menyimpulkan bahwa gambar Allah terdiri dari pengetahuan, kebenaran dan kekudusan yang sesungguhnya (Efesus 4:24). Gambar Allah dalam pengertian yang lebih sempit berarti berfungsinya manusia secara benar di dalam keharmonisan dengan kehendak Allah bagi dirinya. ${ }^{71}$ Dengan demikian, manusia sebagai gambar dan rupa Allah merefleksikan gagasan-gagasan identitas Allah ke dalam totalitas kehidupan mereka dan melakukan apa yang sesuai dengan kehendak-Nya.

\section{Kesimpulan}

Paradigma, dunia, natur, metodologi, pendekatan, dan jenis-jenis antropologi menggiring manusia kepada sebuah tujuan bersama agar apa yang diteliti dalam bingkai hayati humanitas, sosial, budaya, dan agama, dapat memberikan sumbangsih pemikiran dan teladan bagi manusia serta mendorong manusia melakukan hal-hal normatif-etis bagi keberlangsungan hayati, relasi, perdamaian, keharmonisan di lingkungan masyarakat mikro dan makro. Antropologi secara prinsipil tidak hanya bernuasa teoretis melainkan bernuansa etis-aplikatif. Tidak hanya bersandar pada rumusan teori semata, tetapi didukung oleh pengaplikasian nilai-nilai moralitas dan agama bagi kekuatan kebersamaan di tengah perbedaan.

Antropologi itu sendiri berbicara tentang bagaimana kita memahami, menilai manusia dan kehidupannya, dan mengambil kesimpulan sebagai pegangan hidup untuk membentuk pola kehidupan moralitas, spiritualitas, kenyamanan, kedamaian, relasional, kredibel, dan legatif. Kehidupan moralitas berangkat dari gagasan religiositas yang secara masiv dapat dibagikan, dibicarakan, diberitakan, disebarluaskan dalam konteks yang sempit tanpa menyinggung unsur-unsur dispoaritas dogmatis dan iman. Kehidupan spiritualitas seharusnya menjamin kedamaian dan keharmonisan manusia meski terdapat begitu banyak perbedaan. Kehidupan yang berelasi adalah hak mutlak untuk menjalin keakraban, kerja sama, bagi terciptanya kondisi moral dan spiritual antar agama, suku, ras, dan antar golongan. Kehidupan yang kredibel, mencerminkan moralitas dan spiritual manusia yang benar-benar memiliki konsep humanitas, pekerjaan, dan ajaran-ajaran agama secara konsisten dan solid, dan kehidupan yang bersifat legasi adalah sebuah keharusan bagi manusia untuk meneruskan hal-hal baik, berpotensi mengembangkan humanitas dan hayati, serta menciptakan masa depan yang lebih baik.

68 Addison H. Leitch, "Image of God", The Zondervan Pictorial Encyclopedia of the Bible (Grand Rapids: Zondervan, 1975), 3:256. Dikutip Ryrie, Teologi Dasar I, 278.

${ }^{69}$ Bavink, Dogmatika Reformed, 667-68

70 Hoekema, Manusia, 85-86.

71 Hoekema, Manusia, 91. 
Antropologi teologis (biblika) perlu menerapkan ajaran-ajaran Kitab Suci dan mendorong manusia (Gereja Kristus) untuk: 1) menjadi manusia yang mengarahkan dirinya kepada Tuhan; 2) menjadi manusia yang percaya keapda Tuhan; 3) menjadi manusia yang taat (menaati) kepada Tuhan; 4) menjadi manusia yang selalu bersyukur kepada Tuhan; 5) menjadi manusia yang peduli kepada sesamanya; dan 6) menjadi manusia yang mengembangkan potensi alam bagi keberlangsungan hayati.

\section{Referensi}

Berkhof, Louis. Teologi Sistematika: Doktrin Manusia, terj. Yudha Thianto. Surabaya: Momentum, 2013.

Bungin, H. M. Burhan. Sosiologi Komunikasi: Teori, Paradigma dan Diskursus Teknologi Komunikasi di Masyarakat. Jakarta: Kencana, 2011.

Creswell, John W. Penelitian Kualitatif dan Desain Riset. Edisi 3. Yogyakarta: Pustaka Pelajar, 2015.

Creswell, John W. Research Design: Pendekatan Metode Kualitatif, Kuantitatif, dan Campuran, terj. Achmad Fawaid dan Rianayati K. Pancasari. Yogyakarya: Pustaka Pelajar, 2016.

Enns, Paul. The Moody Handbook of Theology, alih bahasa Rahmiati Tanudjaja. Malang: Literatur SAAT, 2003.

Hoekema, Anthony A. Manusia: Ciptaan menurut Gambar Allah, terj. Irwan Tjulianto. Surabaya: Momentum, 2003.

Jamaludin, Adon Nasrullah. Agama \& Konflik Sosial: Studi Kerukunan Umat Beragama, Radikalisme, dan Konflik Antarumat Beragama. Bandung: Pustaka Setia, 2015.

Rachels, James. Filsafat Moral, terj. A. Sudiarja. Yogyakarta: Kanisius, 2017.

Ritzer, George. Teori Sosiologi: Dari Sosiologi Klasik Sampai Perkembangan Terakhir Postmodern, alih bahasa Saut Pasaribu, Rh. Widada, Eka Adi Nugraha. Yogyakarta: Pustaka Pelajar, 2014.

Ryrie, Charles C. Teologi Dasar I: Panduan Populer untuk Memahami Kebenaran Alkitab. Yogyakarta: ANDI, 2014.

Saifuddin, Achmad F. Logika Antropologi: Suatu Percakapan [Imajiner] Mengenai Dasar Paradigma. Jakarta: Prenadamedia Group, 2015.

Saifuddin, Achmad Fedyani. "Agama dalam Pendekatan Sosial Budaya: Dari Positivisme ke Konstruktivisme”, dalam H. M. Ridwan Lubis. Sosiologi Agama: Memahami Perkembangan Agama dan Interaksi Sosial. Jakarta: Prenadamedia Group, 2017.

Thiessen, Henry C. Teologi Sistematika, direvisi oleh Vernon D. Doerksen. Malang: Gandum Mas, 2015.

Widjaja, H. A. W. Komunikasi: Komunikasi dan Hubungan Masyarakat. Jakarta: PT Bumi Aksara, 2002. 